Centro Universitário de Brasília - UniCEUB

Faculdade de Ciências Jurídicas - FAJS

Programa de Iniciação Científica

Vinculação a precedentes jusfundamentais: estudo comparado entre Brasil e Inglaterra

Elisa Cardoso Batista 
Centro Universitário de Brasília - UniCEUB

Faculdade de Ciências Jurídicas - FAJS

Programa de Iniciação Científica

\section{Vinculação a precedentes jusfundamentais: estudo comparado entre Brasil e Inglaterra}

Relatório final apresentado à Assessoria de Pós-Graduação e pesquisa pela Faculdade de Ciências Jurídicas.

Elisa Cardoso Batista

Orientação: Prof. Dra. Christine Oliveira Peter da Silva 


\section{RESUMO}

O objeto do presente trabalho é a sistemática de precedentes, a partir de um recorte comparativo entre os modelos brasileiro e inglês de vinculação a precedentes constitucionais. O objetivo é analisar a vinculação, nos dois sistemas jurídicos em comparação, aos precedentes judiciais constitucionais que interpretam direitos fundamentais. A pesquisa desenvolveu-se por meio da combinação de dois ramos do direito: o direito constitucional e o direito processual civil. No que tange ao direito constitucional, destaca-se o estudo da hermenêutica e concretização de direitos fundamentais, resultando em relatório explicativo de como o Supremo Tribunal Federal tem criado os seus casos notórios jusfundamentais, e também como o mesmo ocorre no modelo constitucional da Inglaterra. Quanto ao direito processual civil, a interferência desse ramo na presente pesquisa tornou-se imprescindível pelo fato de o Código de Processo Civil de 2015 ter, como característica marcante, a valorização da sistemática de precedentes judiciais como mecanismo para assegurar a unidade do Direito, a partir das interpretações judiciais. Com isso, a pesquisa constitui-se como uma comparação analítica, tanto sob o ponto de vista quantitativo (quais são), quanto qualitativo (o que são), acerca das decisões que constituem casos notórios jusfundamentais do Supremo Tribunal Federal e da Suprema Corte Inglesa. Para o âmbito da dogmática e da metódica jurídicas, a imprescindibilidade do método comparativo justifica-se, em parte, em virtude do que se tem identificado como casos notórios que contém debates jusfundamentais. É exatamente nas situações que envolvem conflitos entre direitos fundamentais, cuja concretização não admite anulação ou substituição definitiva de um pelo outro, que a busca por novas fórmulas metódicas ganha maior e mais evidente relevância. Isso porque as decisões, nestas circunstâncias, não mais encontram amparo na fórmula tradicional da subsunção, tal qual proposta pelos juristas dos séculos XVIII e XIX. Assim, a presente pesquisa confirmou a premissa de que a confrontação do intérprete constitucional com outras realidades jurisdicionais (no caso, a Inglaterra), revela que as situações humanas cada vez mais se reproduzem, se interpenetram e se embaralham nos contextos culturais mediados por uma comunicação efetivamente sem fronteiras. Por fim, a partir da presente pesquisa, foi possível reafirmar que os tribunais superiores brasileiros tem utilizado cada vez com maior frequência as técnicas de uniformização de jurisprudência originadas do common law. Contudo, a uniformização do Direito por meio da vinculação a precedentes constitucionais, no Brasil, ainda não é uma garantia institucional, visto que há constantes dificuldades enfrentadas pelas Cortes Superiores brasileiras no que tange à aderência e respeitabilidade às suas decisões.

Palavras-Chave: Direitos Fundamentais. Precedentes Vinculantes. Brasil e Inglaterra. 


\section{SUMÁRIO}

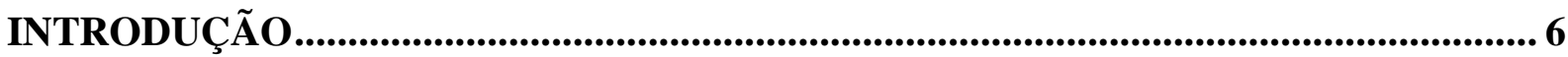

1. EVOLUÇÃO HISTÓRICA DO PRECEDENTE............................................................9

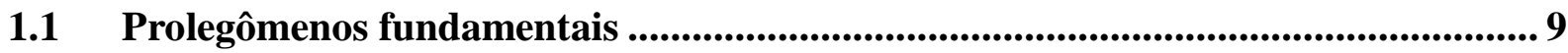

1.2 Do Common Law........................................................................................... 10

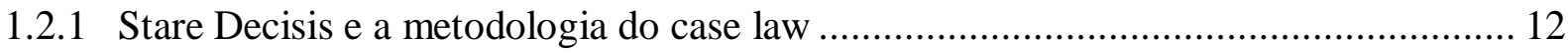

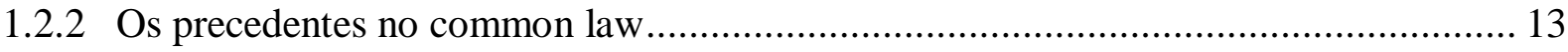

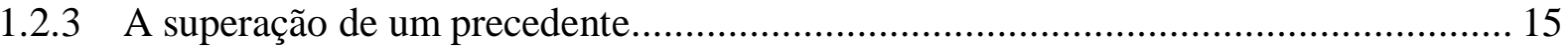

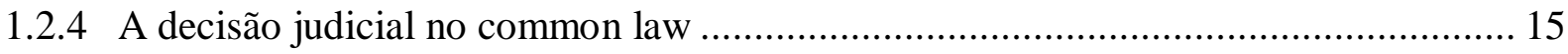

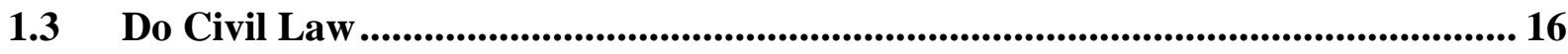

1.3.1 A segurança jurídica decorrente da codificação legal ............................................. 17

1.3.2 A mutação dos limites impostos à interpretação judicial ........................................ 19

1.4 Da mitigação de ambos os sistemas.............................................................. 20

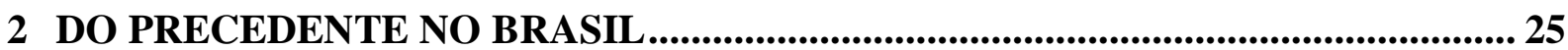

2.1 As marcas do common law no sistema jurídico brasileiro .................................... 25

2.2 A conceituação do precedente ................................................................................. 29

2.2.1 O precedente, a sua conceituação e a decisão judicial .............................................. 29

2.2.2 O precedente e a jurisprudência ........................................................................... 30

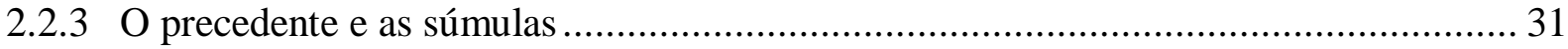

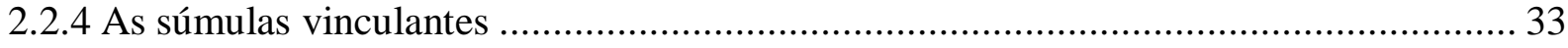

2.3 A função do precedente no Código de Processo Civil de 2015 ............................... 34

2.3.1 Institutos caracterizadores do precedente no Novo Código de Processo Civil............. 36

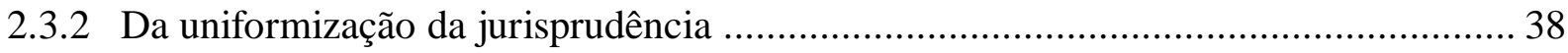

2.3.3 Da possibilidade de alteração de entendimento jurisprudencial ................................ 40

2.3.4 Da modulação dos efeitos da alteração de um entendimento jurisprudencial .............. 41

2.3.5 O incidente de resolução de demandas repetitivas.................................................. 42

3 DA RELAÇÃO DO PRECEDENTE COM O ESTADO DE DIREITOS

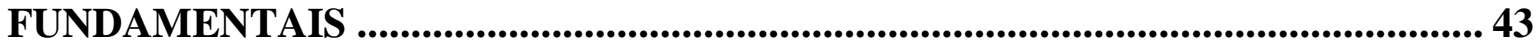


3.1 Da supremacia da constituição resultante na interdependência entre as Funções de Poder 43

3.2 Os Direitos Fundamentais e o Processo ............................................................... 45

3.3 Os Precedentes e os Direitos Fundamentais ........................................................ 48

4 DOS RESULTADOS DA PESQUISA ........................................................................... 50

4.1 Da metodologia utilizada ..................................................................................................... 50

4.2 Dos resultados referentes aos anos de 2010 a 2015 na Inglaterra......................... 51

4.3 Dos resultados referentes aos anos de 2010 a 2015 no Brasil............................... 54

CONCLUSÃO

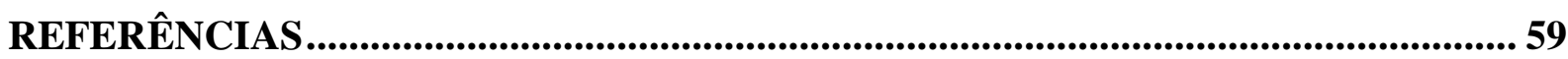




\section{INTRODUÇÃO}

O problema da presente pesquisa encontra-se na metodologia de utilização do precedente na tomada de decisões pelos Tribunais Superiores do Brasil. Essa pesquisa fora desenvolvida no plano teórico do Direito Constitucional, destacando-se o papel fundamental da disciplina da hermenêutica e da concretização dos direitos fundamentais trazidos no texto constitucional. Verifica-se como tem ocorrido a aplicação dos precedentes no Direito Brasileiro a partir de uma analise comparativa com países do common law, especificamente com a Inglaterra.

A presente pesquisa justifica-se, num primeiro plano, porque ainda não são abundantes as investigações acerca das diferenças e semelhanças substanciais entre o modelo de vinculação a precedentes judiciais constitucionais experimentado no Brasil e na Inglaterra. Os questionamentos acerca dos detalhes históricos, jurídicoprocedimentais e institucionais do modelo de stare decisis e do modelo brasileiro de vinculação a precedentes constitucionais, especialmente aqueles que interpretam direitos fundamentais, é algo de importância crucial para o jurista contemporâneo, tendo em vista a importância cada vez maior da jurisprudência como fonte de Direito. Assim, a partir de uma analise pragmática, conclui-se que não há dados empíricos resultantes da comparação a aplicação dos precedentes no Brasil com a aplicação desses em países oriundos do common law.

A utilização de métodos comparativos se justifica, acime de tudo, pelo fato de o desenvolvimento do direito ter resultado em uma comunicação cada vez maior entre as diferentes culturas, fazendo com que os Países tenham suas realidades jurídicas cada vez mais interpenetradas umas nas outras. Assim, para o jurista do século XXI, a mera analise do seu direito local não tem se mostrado suficiente para o fornecimento de respostas buscadas pelos jurisdicionados. Recorre-se a uma transcendência do Direito, o que, a partir dessa pesquisa, conclui-se que somente é possível a partir da utilização do Direito Comparado.

Com isso, o objetivo da presente pesquisa é comparar as decisões do Supremo Tribunal Federal e da Corte Suprema Britânica, que constituam casos notórios de direitos fundamentais, para descrever, por meio de relatório analítico, quais direitos fundamentais foram concretizados pelas Cortes e como se dá a 
vinculação a tais precedentes no ordenamento constitucional brasileiro e no ordenamento constitucional inglês.

Quanto aos objetivos específicos da pesquisa, busca-se identificar como ocorrem os julgamentos de casos notórios que envolvam direitos fundamentais nas duas Cortes em comparação, para descrever quais são os direitos fundamentais prevalentemente julgados entre 2010 a 2015. Com isso, utiliza-se relatório analítico, com aspectos descritivos e explicativos sobre as semelhanças e diferenças entre os modelos de vinculação a precedentes firmados pelo Supremo Tribunal Federal e pela Suprema Corte Britânica.

São criadas, também, duas tabelas detalhadas sobre os casos relevantes de ambos os Países. No que tange ao Brasil, traz-se os casos considerados notórios pelo Supremo Tribunal Federal. No âmbito da Inglaterra, traz-se os casos utilizados como fontes de precedentes no direito anglo-saxão. Em suma, busca-se especificar semelhanças e diferenças no que diz respeito ao método de uniformização de jurisprudência nesses Países.

Desse modo, o principal marco teórico da pesquisa é a proposta do professor Peter Häberle, uma vez que este traz o método comparativo como quinto elemento de interpretação jurídica1 ${ }^{1}$. Além disso, tem-se como referencial teórico a teoria do "Estado de Direitos Fundamentais", proposta pela Professa Doutora Christine de Oliveira Peter da Silva, a metodologia dogmática de Luiz Guilherme Marinoni, proposta em "A Ética dos Precedentes" e "Julgamento nas Cortes Supremas, Precedente e Decisão do Recurso Diante do Novo CPC", o método proposto por Daniel Mitidiero, em "Precedentes, da persuasão à vinculação", bem como com a obra de Júlio César Rossi, "Precedente à Brasileira: A Jurisprudência Vinculante no CPC e no Novo CPC" e a de Gilberto Andreassa Junior, em "Os "Precedentes" no Sistema Jurídico Brasileiro (STF E STJ), além de outros autores citados no desenvolvimento da pesquisa.

A pesquisa proposta desafia a estudante de iniciação científica a conhecer dois sistemas constitucionais aparentemente diversos, mas que certamente sofreram e sofrem influências recíprocas não tão óbvias. A obrigatoriedade de observância das

\footnotetext{
${ }^{1}$ HÄBERLE, Peter. El estado constitucional. Tradução de Hector Fix-Fierro. México: Universidad Nacional Autônoma de México, 2003, p. 162.
} 
decisões jusfundamentais das Cortes Supremas impõe que sejam questionados os métodos e os procedimentos para essa vinculação. Essa é uma justificativa relevante do presente projeto.

Esse é o contexto teórico em que é desenvolvida a pesquisa proposta, de modo que a comparação entre os sistemas brasileiro e inglês, no que diz respeito à vinculação a precedentes jusfundamentais das respectivas Supremas Cortes, apresenta-se como desdobramento dos desafios apresentados pelo neoconstitucionalismo.

A pesquisa proposta no presente projeto é de análise comparativa, tanto sob o ponto de vista quantitativo (quais são) quanto qualitativo (o que são), acerca das decisões que constituem casos notórios jusfundamentais do Supremo Tribunal Federal e da Suprema Corte Inglesa. As técnicas de pesquisa serão combinadas, tanto a bibliográfica (documentação indireta) quanto a documental (documentação direta), uma vez que se trata de tema que exige tanto a pesquisa de bibliografia pátria e estrangeira (inglesa), quanto também uma séria e ampla abordagem documental (análise dos precedentes das duas Supremas Cortes).

Para a análise dos precedentes do Supremo Tribunal Federal, vai-se fazer busca exploratória, por meio de pesquisa quantitativa, no sítio da Corte Suprema Brasileira em uma lista já disponível de Casos Notórios da Corte, para a partir dessa lista, fazendo o corte temporal de 2010 a 2015, identificar aqueles casos que tratem tipicamente de concretização de direitos fundamentais (casos jusfundamentais).

Para a análise dos precedentes da Suprema Corte Inglesa, a pesquisa exploratória envolverá a busca de todos os casos julgados entre os anos de 2010 e 2015 para identificar as temáticas e partir disso classificar os casos jusfundamentais.

Após a catalogação (pesquisa quantitativa), vai-se proceder a uma análise dos argumentos utilizados para verificar as teses vinculantes e a partir delas explicitar os modelos de vinculação a esses precedentes em um e outro sistema. Também serão geradas tabelas com os dados quantitativos encontrados, juntamente com um resumo dos casos julgados.

Por fim, a presente pesquisa tem como objetivo demonstrar que, apesar de o ordenamento jurídico brasileiro ser composto por diversos instrumentos capazes de garantir a uniformidade do direito, ainda há pouco comprometimento das Cortes 
Inferiores no que tange a respeitabilidade dessas decisões tomadas pelas Cortes Superiores. Há, portanto, um longo caminho para que o sistema jurídico brasileiro alcance a confiabilidade garantida nas decisões tomadas pelos juízes do common law.

\section{EVOLUÇÃO HISTÓRICA DO PRECEDENTE}

\subsection{Prolegômenos fundamentais}

Para que haja uma melhor análise do precedente, pincipalmente no que tange ao comparativismo constitucional, é imprescindível que seja feita uma análise do desenvolvimento desse instituto nos sistemas do common law e civil law. Essa analise se justifica, também, pelo fato de o civil law ser o sistema característico do ordenamento jurídico brasileiro, enquanto o common law é o sistema do ordenamento jurídico inglês.

A cultura jurídica do ocidente pode ser bifurcada em duas diretrizes diferentes no que tange à orientação do Direito. Divide-se entre os países que recepcionaram o Direito romano e as codificações criadas mais tarde segundo a imagem do Código Justiniano e, por outro lado, entre os países do case law anglosaxão. No primeiro caso, o legislador é o autor do direito; no segundo caso, o juiz. ${ }^{2}$

Common Law e Civil Law são os codinomes dados às duas famílias de tradições jurídicas que exercem constantes influencias em grande parte dos sistemas jurídicos contemporâneos existentes, caracterizando as duas bifurcações da cultura jurídica do ocidente. Assim, conforme supracitado, esses sistemas tem como diferenciação básica o modo pelo qual é realizada a interpretação do Direito, uma vez que no common law o juiz é o autor do direito, enquanto no civil law o legislador é o autor. $^{3}$

Para se conhecer esses sistemas jurídicos, deve haver um estudo prévio de seus contextos históricos, visto que o common law e civil law surgiram em circunstancias distintas, fazendo com que cada sistema possua suas peculiaridades

\footnotetext{
${ }^{2}$ RADBRUCH, Gustav. O Espírito do Direito Inglês e a Jurisprudência Anglo-Americana. Rio de Janeiro: Editora Lumen Juris, 2010. p. 33

${ }^{3}$ ROSSI, Júlio César. Precedente à Brasileira: A Jurisprudência Vinculante no CPC e no Novo CPC. São Paulo: Editora Atlas, 2015. p.43.
} 
e métodos de atuação. ${ }^{4}$.Por isso, eles levaram à formação de diferentes tradições jurídicas, que foram definidas por institutos e conceitos próprios em cada um dos sistemas. $^{5}$

Essas estruturas jurídicas vêm sendo cada vez mais mitigadas, em razão da dinâmica do Direito. Isso tem ocorrido porque os países associados ao common law têm utilizado com maior frequência códigos, enquanto os países associados ao civil law têm dado maior atenção à elaboração e qualificação de seus precedentes. ${ }^{6}$

Insta salientar que, na presente pesquisa, o que for tratado como Direito no common law pode ser considerado como o direito especificamente na Inglaterra, haja vista o direito inglês ser um desdobramento do common law. Com isso, o estudo prévio e detalhado de ambos os sistemas é imprescindível para a compreensão do precedente e de seu desenvolvimento nos Países do Civil Law, especificamente no Brasil.

\subsection{Do Common Law}

O common law é o sistema jurídico adotado nos Países de origem anglosaxônica. Por ter seu berço na Inglaterra, todo o estudo do common law deve começar pelo estudo daquele País, principalmente quando se pretende compará-lo com os países do civil law. ${ }^{7}$ Portanto, esse sistema surgiu na Inglaterra e foi consolidado com a Revolução Gloriosa de 1688.

A Revolução Gloriosa foi marcada, substancialmente, pela luta da burguesia inglesa contra o absolutismo real. Essa luta foi embasada na busca da garantia de liberdades individuais. Ainda que tenha o codinome "revolução", esta teve um caráter extremamente conservador, visto que não buscou romper com o direito do passado, mas assegurar que os monarcas também se submeteriam aos direitos individuais dos cidadãos e da propriedade. Com isso, o sistema é considerado um

\footnotetext{
${ }^{4}$ ANDREASSA JUNIOR, Gilberto. Ativismo Judicial e Teoria dos Precedentes. Integração dos Poderes e Coerência nas Decisões do Judiciário, Curitiba: Juruá Editora, 2015. p.13. 5 MARINONI, Luiz Guilherme. Aproximação crítica entre as jurisdições de civil law e de common law e a necessidade de respeito aos precedentes no Brasil. Revista da Faculdade de Direito UFPR, Curitiba, n.49, p. 11-58, 2009..

${ }^{6}$ ANDREASSA JUNIOR, Gilberto. Ativismo Judicial e Teoria dos Precedentes. Integração dos Poderes e Coerência nas Decisões do Judiciário, Curitiba: Juruá Editora, 2015. p.14.

${ }^{7}$ MITIDIERO, Daniel. Precedentes, da persuasão à vinculação. São Paulo: Editora Revista dos Tribunais LTDA, 2016. p.28.
} 
continum histórico, uma vez que se mantém através de um desenvolvimento ininterrupto, acumulando experiência e sabedoria de séculos ${ }^{8}$

Nesse contexto histórico, surge o common law.. Diferentemente do que ocorreu no desenvolvimento histórico do civil law, aqueles que conduziram a Revolução Inglesa não consideravam os juízes uma ameaça, mas sim, um poder amigo do parlamento na luta contra as arbitrariedades do rei. 9

Vale salientar que este sistema é oriundo do direito comum, ou seja, dos costumes gerais. Assim, o common law pode ser entendido como "o direito desenvolvido pelos juízes, independente de uma corporificação em normas codificadas como ocorre no civil law". 10

De acordo com Luiz Guilherme Marinoni, descrevendo o contraste entre e Revolução Inglesa de 1688 e a Revolução Francesa de 1789, assevera que:

\begin{abstract}
"A afirmação do Parlamento, sublinhada pela Revolução Inglesa de 1688 , não teve o propósito de marcar o início de um novo direito, como já dito. O seu caráter foi conservador. Afirmou-se que a Revolução não foi dotada de verdadeiro 'espírito revolucionário', não desejou desconsiderar o passado e destruir o direito já existente, mas, ao contrário, confirmá-lo e fazê-lo valer contra um rei que não o respeitava.

(...) tendo-se em vista que, na Inglaterra, a lei não objetivava expressar um direito novo, mas representava mero elemento introduzido em um direito ancestral (o qual, antes de merecer repulsa, era ancorado na história e nas tradições do povo inglês), e ainda que o juiz era visto como 'amigo' do poder que se instalara (uma vez que sempre lutara, misturado ao legislador, contra o absolutismo do rei), não houve qualquer intenção ou necessidade de submeter ai juiz inglês à lei.

Além de a lei jamais ter anulado o poder do juiz, os próprios princípios da Revolução Inglesa davam-Ihe condição para controlar os atos legislativos a partir do common law, já que o Parlamento, embora supremo diante no monarca, era àquele submetido". ${ }^{11}$
\end{abstract}

Portanto, este sistema se desenvolveu pela recusa de se recepcionar 0 direito romano. Com isso, houve uma maior valorização das próprias decisões tomadas pelos juízes, fazendo com que essas passassem a se tornar direitos. Ainda

\footnotetext{
${ }^{8}$ ANDREASSA JUNIOR, Gilberto. Ativismo Judicial e Teoria dos Precedentes. Integração dos Poderes e Coerência nas Decisões do Judiciário, Curitiba: Juruá Editora, 2015. p. 21.

${ }^{9}$ ANDREASSA JUNIOR, Gilberto. Ativismo Judicial e Teoria dos Precedentes. Integração dos Poderes e Coerência nas Decisões do Judiciário, Curitiba: Juruá Editora, 2015. p 20.

${ }^{10}$ ANDREASSA JUNIOR, Gilberto. Ativismo Judicial e Teoria dos Precedentes. Integração dos

Poderes e Coerência nas Decisões do Judiciário, Curitiba: Juruá Editora, 2015. p $20 .$.

${ }^{11}$ MARINONI, Luiz Guilherme. O STJ enquanto corte de precedentes. Recompreensão do

Sistema Processual da Corte Suprema. São Paulo: Editora Revista dos Tribunais, 2013. p46-48.
} 
que a teoria do common law exista muito antes dos precedentes, foi expansão na confiança das decisões que fez surgir a teoria dos precedentes. ${ }^{12}$

Vale salientar que na Inglaterra, por exemplo, a Câmara dos Lordes veio a admitir o caráter vinculativo de suas decisões em 1861 em Beamish vs Beamish, mas ganhou força em 1898 com London Street Tamways vs. London County Council, quando o tribunal considerou devido zelar pela segurança jurídica, como vê-se nas palavras do Lord Chancellor, o Lord Halsbury Assim, foi a partir desse caso que foi estabelecido que a House of Lords Estaria vinculada aos precedentes. ${ }^{13}$

\subsubsection{Stare Decisis e a metodologia do case law}

Conforme previamente salientado, o juiz no common law não é tão vinculado à letra da lei assim como é o juiz do civil law. Contudo, esse fato não é sinônimo de que este mesmo juiz seja livre para ignorar ou descumprir as disposições legais. A essência do sistema baseado em precedentes é a flexão jurídica que leva em consideração fatores além do expressamente disposto no texto legal, a exemplo de princípios, moral e costumes. ${ }^{14}$

O Stare Decisis e sua teoria são relacionados ao ditado latim "stare decisis et non quieta movere", que significa "mantenha-se a decisão e não ofenda o que foi decidido". ${ }^{15}$ Assim, a força vinculante das decisões tomadas no Direito Inglês partiu da valorização do Direito Consuetudinário do País, visando preservar o direito formado a partir de sua cultura e desenvolvimento histórico. ${ }^{16}$

Este sistema, que utiliza as decisões passadas para embasar decisões futuras, é chamado, também, de case law. Essa outra denominação se dá em decorrência da alta utilização de jurisprudências para decisões a serem tomadas, em que se aderem casos específicos pretéritos e buscam-se reproduzir o direito ali vinculado para situações futuras semelhantes.

\footnotetext{
${ }^{12}$ ANDREASSA JUNIOR, Gilberto. Ativismo Judicial e Teoria dos Precedentes. Integração dos Poderes e Coerência nas Decisões do Judiciário, Curitiba: Juruá Editora, 2015. p. 22 ${ }_{13}$ ANDREASSA JUNIOR, Gilberto. Ativismo Judicial e Teoria dos Precedentes. Integração dos Poderes e Coerência nas Decisões do Judiciário, Curitiba: Juruá Editora, 2015. p. 22 ${ }^{14}$ ANDREASSA JUNIOR, Gilberto. Ativismo Judicial e Teoria dos Precedentes. Integração dos Poderes e Coerência nas Decisões do Judiciário, Curitiba: Juruá Editora, 2015. p 65 e 68. ${ }^{15}$ TEODORO, Rafael Theodor. A Teoria do Stare Decisis no Controle de Constitucionalidade Brasileiro. Disponível em: <https:/jus.com.br/artigos/25383/a-teoria-do-stare-decisis-no-controle-deconstitucionalidade-brasileiro>. Aceso em 06/06/2017.

${ }^{16}$ RADBRUCH, Gustav. O Espírito do Direito Inglês e a Jurisprudência Anglo-Americana. Rio de Janeiro: Editora Lumen Juris, 2010. p. 55.
} 
O case law não é sinônimo de reprodução discricionária das decisões pretéritas apenas pela mera semelhança entre os casos. Não há uma reprodução ininterrupta das decisões tomadas previamente, uma vez que se criaria um enfadonho processo de transcrição de cada caso-base de precedentes. Isso ocorre, pois, o que é necessário, a fundo, é a reprodução do conteúdo do precedente, ou seja, daquele direito criado. Assim, diz-se que o case law caracteriza um sistema jurídico empíricoindutivo, visto que a essência do direito deve ser buscada a partir de casos que se encontram dormentes e estabeleceram algum direito para a sociedade no passado, refletindo-se no caso concreto presente. ${ }^{17}$

\subsubsection{Os precedentes no common law}

De acordo com Teresa Arruda Alvim Wambier, a vinculação aos precedentes no common law não aconteceu de maneira previamente delineada. Ocorreu de maneira despercebida, a partir do momento em que se começou a ter o direito costumeiro como sinônimo das decisões tomadas em casos de diversas partes do Reino Unido. Assim, diferentemente do que se imagina, não houve uma postulação especifica de que as decisões anteriores passariam a ser vinculantes. ${ }^{18}$

Essa é a diferença substancial entre o stare decisis e o common law. Conforme demonstrado no tópico anterior, o stare decisis é um tido como uma regulamentação do precedente que viabiliza a extração de um parte da decisão que deve ser replicada e respeitada, adquirindo força de precedente. Já o common law é a aplicação do direito costumeiro sem nenhuma regulamentação, ou seja, costumes gerais que direcionam o comportamento do Englishmen, independente de um rule of precedente. Nesse ponto, vale salientar, também, que o stare decisis também é diferente da teoria dos precedentes judiciais, visto que o primeiro é a força vinculante de uma decisão especifica, enquanto o segundo trata de uma linha de decisões tomadas por juízes em um mesmo sentido. ${ }^{19}$

\footnotetext{
${ }^{17}$ RADBRUCH, Gustav. O Espírito do Direito Inglês e a Jurisprudência Anglo-Americana. Rio de Janeiro: Editora Lumen Juris, 2010. p. 57.

${ }^{18}$ KREBS, Hélio Ricardo Diniz. Sistemas de Precedentes e Direitos Fundamentais. São Paulo, Editora Revista dos Tribunais LTDA, 2015, p.86.

${ }^{19}$ LEAL, Diego de Lima. A Doctrine of Stare Decisis a Common Law e os Precedentes Judiciais. Disponível em:< https://diegoleal.jusbrasil.com.br/artigos/296841745/a-doctrine-of-stare-decisis-acommon-law-e-os-precedentes-judiciais>.Acesso em 07 de junho de 2017.
} 
Deve-se deixar claro que o costume e o precedente são ocorrências distintas, visto que é possível um precedente independente de um costume, assim como um costume independente da existência de um precedente. Contudo, ainda que sejam instrumentos interpretativos distintos, os costumes gerais do Englishmen tendem a ser incorporados às decisões judiciais como precedentes.. ${ }^{20}$

Vale salientar que este sistema objetiva garantir que os juízes não tomem decisões que não correspondam com o esperado pela sociedade. Isso ocorre, pois, os cidadãos baseiam suas condutas nas decisões que são tomadas pelo Poder Judiciário. Portanto, essa previsibilidade não passa de uma garantia do Estado de Direito que valoriza a obediência aos precedentes. ${ }^{21}$

O precedente tomado com uma função ilustrativa e embasadora de futuras decisões surgiu a partir do case law. Esse case law é a expressão de que o direito inglês é aquele criado caso-a-caso nas decisões judiciais que são tomadas pelos juízes. Assim, o precedente vem como fonte explicativa dessas interpretações, assumindo papel criador do sistema jurídico. ${ }^{22}$

Como o precedente passaria a ter a função de "criador do Direito", ilustrando o entendimento fomentado nas decisões judiciais, surge a dificuldade de se saber qual decisão realmente basearia um precedente. Assim, surge-se a hierarquização das decisões judiciais para a devida caracterização do precedente. ${ }^{23}$

Para solucionar esse problema de vinculação dos precedentes e visando racionalizar o sistema jurídico, especificamente na Inglaterra, foram outorgados os os Judicature Acts de 1873-1875. Esses acts estruturaram o sistema jurídico inglês, estabelecendo um sistema hierárquico, a exemplo de uma pirâmide, em que 0 ápice dessa é a Supreme Court of the United Kingdom. O topo da pirâmide foi estabelecido, minuciosamente, pelo Constitutional Reform Act de 2005.24

\footnotetext{
${ }^{20}$ ANDREASSA JUNIOR, Gilberto. Ativismo Judicial e Teoria dos Precedentes. Integração dos Poderes e Coerência nas Decisões do Judiciário, Curitiba: Juruá Editora, 2015. p 66-67.

${ }^{21}$ KREBS, Hélio Ricardo Diniz. Sistemas de Precedentes e Direitos Fundamentais. São Paulo, Editora Revista dos Tribunais LTDA, 2015, p.94.

${ }^{22}$ MITIDIERO, Daniel. Precedentes, da persuasão à vinculação. São Paulo: Editora Revista dos Tribunais LTDA, 2016. p. 29-30.

${ }^{23}$ MITIDIERO, Daniel. Precedentes, da persuasão à vinculação. São Paulo: Editora Revista dos Tribunais LTDA, 2016. p. 29-30.

${ }^{24}$ MITIDIERO, Daniel. Precedentes, da persuasão à vinculação. São Paulo: Editora Revista dos Tribunais LTDA, 2016. p. 41.
} 


\subsubsection{A superação de um precedente}

A fim de evitar que os precedentes judiciais se tornem "gessos" para a interpretação jurídica inglesa a partir da mutação sofrida pela sociedade com o tempo, foram criados métodos para superação do direito previamente firmado. Esses métodos visam garantir a segurança da movimentação do jurídico e são denominados overruling e distinguishing, em que o juiz deve, expressa e justificadamente, expor as razões para a não aplicação do precedente. .

O overruling consiste na superação do precedente, ou seja, é uma espécie de revogação que visa confirmar o novo direito desenvolvido na sociedade. O objetivo desse instituto é garantir que o direito estabelecido nas cortes tenha sempre uma congruência social. ${ }^{25}$

$O$ distinguishing consiste na distinção entre 0 caso que fundamenta 0 precedente e o caso sob julgamento. Assim, busca-se estabelecer diferenças entre a ratio decidendi da obiter dicta. Portanto, a partir desses institutos, é possível que determinado juiz entenda que determinado precedente, ainda que semelhante, não é adequado para aquele caso concreto.. ${ }^{26}$

\subsubsection{A decisão judicial no common law}

Para finalizar a analise dos precedentes no common law, é imprescindível tratar da denominação dada às partes das decisões, a fim de se destacar quais são importantes para a futura vinculação e quais não são. Essas classificações são denominadas ratio decidendi e obter dictum. ${ }^{27}$

A ratio decidendi consiste nos fundamentos jurídicos que sustentam as decisões judiciais e que visam solucionar os casos sob a analise do common law. Essa ratio é de extrema importância no sistema, visto que busca destacar os elementos sociológicos, históricos e psicológicos que dão embasamento às decisões

\footnotetext{
${ }^{25}$ ANDREASSA JUNIOR, Gilberto.. Os "Precedentes" no Sistema Jurídico Brasileiro (STF E STJ). Disponível em: < http://andreassaeandreassa.adv.br/wp-content/uploads/2013/09/Osprecedentes-no-Brasil-STF-e-STJ.pdf> Acesso em: 08 dez. 2016.

${ }^{26}$ ANDREASSA JUNIOR, Gilberto.. Os "Precedentes" no Sistema Jurídico Brasileiro (STF E STJ). Disponível em: < http://andreassaeandreassa.adv.br/wp-content/uploads/2013/09/Osprecedentes-no-Brasil-STF-e-STJ.pdf> Acesso em: 08 dez. 2016.

${ }^{27}$ ANDREASSA JUNIOR, Gilberto. Os "Precedentes" no Sistema Jurídico Brasileiro (STF E STJ). Disponível em: < http://andreassaeandreassa.adv.br/wp-content/uploads/2013/09/Os-precedentes-noBrasil-STF-e-STJ.pdf> Acesso em: 08 dez. 2016.
} 
judiciais, expandindo a importância da decisão para além das partes envolvidas no processo. ${ }^{28}$

A obter dictum é considerada uma parte fundamental da decisão tomada pelo juiz, mas é dispensável no que tange à formação do precedente. Nela consistem todos os fundamentos utilizados de maneira acessória no veredito tomado, aprofundando a questão de direito. ${ }^{29}$

Quando se diz que o juiz do common law cria o direito, não se está pensando que a sua decisão tem a mesma força e qualidade do produto elaborado pelo Legislativo, isto é, da lei. A decisão não se equipara à lei pelo fato de ter força obrigatória para os demais juízes. ${ }^{30} E$ verdade que o common law considera o precedente como fonte de direito. Note-se, contudo, que quando um precedente interpreta a lei ou a Constituição, há, evidentemente, direito preexistente com força normativa, de modo que seria absurdo pensar que o juiz, neste caso, cria um direito novo, sem qualquer parâmetro anterior que o balize.

A fim de concluir, é valido trazer em questão o considerado por Ronald Dworkin, que diz que "a ideia de precedentes é como um romance em cadeia, isto é, cada julgador deve agir como se estivesse escrevendo o capítulo de um romance, devendo, para tanto, partir do capítulo anterior para poder avançar". ${ }^{31}$ Assim, ele salienta que a ideia de direito mais próxima daquilo que pode ser considerado o ideal nas soluções das lides é o Common Law, visto que sua formação transcende os escritos legais. ${ }^{32}$

\subsection{Do Civil Law}

O Civil Law é a estrutura jurídica desenvolvida a partir da grande influencia do Direito Romano, resultando na codificação do Direito. Nessa estrutura jurídica, a

\footnotetext{
${ }^{28}$ ANDREASSA JUNIOR, Gilberto. Ativismo Judicial e Teoria dos Precedentes. Integração dos Poderes e Coerência nas Decisões do Judiciário, Curitiba: Juruá Editora, 2015. p. 67 e 68. ${ }_{29}$ ANDREASSA JUNIOR, Gilberto. . Ativismo Judicial e Teoria dos Precedentes. Integração dos Poderes e Coerência nas Decisões do Judiciário, Curitiba: Juruá Editora, 2015. p. 68. 30 MARINONI, Luiz Guilherme. Aproximação crítica entre as jurisdições de civil law e de common law e a necessidade de respeito aos precedentes no Brasil. Revista da Faculdade de Direito - UFPR, Curitiba, n. 497, p. 19, 2009.

${ }^{31}$ DWORKIN, Ronald. O império do Direito. 2. ed. 2 $2^{a}$ tiragem. São Paulo: Martins Fontes, 2010

${ }^{32}$ ANDREASSA JUNIOR, Gilberto Os "Precedentes" no Sistema Jurídico Brasileiro (STF e STJ). Disponível em: < http://andreassaeandreassa.adv.br/wp-content/uploads/2013/09/Os-precedentes-noBrasil-STF-e-STJ.pdf> Acesso em: 08 dez. 2016.
} 
elaboração das leis deve ser restrita ao Poder Legislativo, buscando-se, a partir disso, afastar a possibilidade de criação do direito pelo Poder Judiciário. ${ }^{33}$

A busca pelo rompimento de qualquer dependência do desenvolvimento do direito a partir das funções do Judiciário ocorreu devido ao fato de que, antes da Revolução Francesa, a classe de juízes era aristocrática, ou seja, não tinham atitudes condizentes com os ideais trazidos pela Revolução (Igualdade, Liberdade e Fraternidade). Essa aristocracia resultava em laços com as classes privilegiadas da sociedade, fazendo com que as decisões tomadas fossem influenciada por diversos interesses pessoais de cada magistrado. ${ }^{34}$

No que tange ao desenvolvimento histórico do civil law, vale salientar que o sistema jurídico em questão é composto por elementos históricos distintos. O seu marco histórico mais antigo encontra-se no século VI d.C, em que houve a compilação das leis em código por Justiniano. Essa codificação veio com o objetivo de garantir a confiança no direito, evitando que houvessem diversas leis esparças e consequente insegurança jurídica. Assim, foi elaborado Corpus Juris Civilis como resposta à constante mutação do Direito. ${ }^{35}$

\subsubsection{A segurança jurídica decorrente da codificação legal}

A unificação do Direito em apenas uma única fonte é uma garantia da segurança jurídica dos jurisdicionados, visto que, ao se ter diversas fontes fragmentadas em textos esparsos, aumentava-se a chance de os juízes exercerem suas interpretações de maneira discricionária e em proveito próprio. Assim, foi a primeira limitação dos excessivos poderes que estavam concentrados nas mãos dos juízes. ${ }^{36}$

É fenômeno indiscutível que a Revolução Francesa foi um marco fundamental no desenvolvimento do direito no civil law. Júlio César Rossi destaca que esta foi a "grande precursora do movimento da codificação", principalmente pelo fato

\footnotetext{
${ }^{33}$ ANDREASSA JUNIOR, Gilberto. Ativismo Judicial e Teoria dos Precedentes. Integração dos Poderes e Coerência nas Decisões do Judiciário, Curitiba: Juruá Editora, 2015. p. 23.

${ }^{34}$ ANDREASSA JUNIOR, Gilberto. Ativismo Judicial e Teoria dos Precedentes. Integração dos Poderes e Coerência nas Decisões do Judiciário, Curitiba: Juruá Editora, 2015. p. 24 ${ }^{35} \mathrm{ROSSI}$, Júlio César. Precedente à Brasileira: A Jurisprudência Vinculante no CPC e no Novo CPC. São Paulo: Editora Atlas, 2015. p. 60.

${ }^{36}$ MITIDIERO, Daniel. Precedentes, da persuasão à vinculação. São Paulo: Editora Revista dos Tribunais LTDA, 2016. p. 47.
} 
de se ter, a partir dela, considerado a real necessidade de separação dos poderes. Assim, o poder de criar o direito converge para o Poder Legislativo, restando ao Poder Judiciário a analise dos casos concretos e sua confrontação com o texto legal, julgando-se de maneira vinculada ao disposto na lei.. ${ }^{37}$

Portanto, essa separação rígida dos Poderes, buscando limitar as funções exercidas pelos juízes, decorreu do desejo nacional da criação de um direito novo, independente da influencia da classe privilegiada da sociedade e baseado na teoria trazida por Montesquieu. Esse modelo é marcado por uma rompedora com o direito antigo e pela formação de um Direito Civil moderno. ${ }^{38}$

Sobre a teoria trazida por Montesquieu e sua influencia no sistema jurídico em questão, utilizou-se o ideal de que os poderes não deviam ser superconcentrados. Assim, o Judiciário, como um dos Poderes, devia sofrer limitação e ter como função apenas a aplicação da lei. Utiliza-se, também, a teoria de Rousseau, segundo a qual toda vontade do povo francês devia estar codificada em leis escritas. ${ }^{39}$

Vale salientar que o processo de constitucionalização do Direito, ocorrido em meados do século XVIII, gerou profundas mudanças no sistema do civil law. Esse movimento teve como marco principal o fato de trazer ao direito uma rigidez funcional, que consiste, em suma, no fato de a constituição ser o topo da pirâmide das fontes do Direito e, com isso, a norma superior a todas as demais fontes. ${ }^{40}$

Portanto, na tradição do civil law, a fonte mais valorizada é a legal. Isso ocorre pois esta é a fonte primaria e principal, cabendo às jurisprudências, costume e doutrina o papel de fontes segundarias e mediatas no ordenamento jurídico. A partir dessa ideia é capaz de extrair a grande mutação trazida pelos movimentos constitucionalistas ao civil law, visto que, como a fonte primaria é a lei e as Constituições vieram como a "lei acima da lei", estas tornaram-se as fontes máximas e superiores a qualquer outra fonte de direito, ainda que legal. ${ }^{41}$

\footnotetext{
${ }^{37}$ ROSSI, Júlio César. Precedente à Brasileira: A Jurisprudência Vinculante no CPC e no Novo CPC. São Paulo: Editora Atlas, 2015. p.71.

${ }^{38}$ ANDREASSA JUNIOR, Gilberto. Ativismo Judicial e Teoria dos Precedentes. Integração dos Poderes e Coerência nas Decisões do Judiciário, Curitiba: Juruá Editora, 2015. p. 24.

${ }^{39}$ KREBS, Hélio Ricardo Diniz. Sistemas de Precedentes e Direitos Fundamentais. São Paulo: Editora Revista dos Tribunais LTDA, 2015, p.112.

${ }^{40}$ ROSSI, Júlio César. Precedente à Brasileira: A Jurisprudência Vinculante no CPC e no Novo CPC. São Paulo: Editora Atlas, 2015. p. .68.

${ }^{41}$ ROSSI, Júlio César. Precedente à Brasileira: A Jurisprudência Vinculante no CPC e no Novo CPC. São Paulo: Editora Atlas, 2015. p. 69.
} 


\subsubsection{A mutação dos limites impostos à interpretação judicial}

Para finalizar essa primeira análise histórica do civil law, é necessário esclarecer de onde surge essa proibição dos juízes para interpretar a lei. Durante o período do ancien regime ${ }^{42}$, em que os membros do Poder Judiciário distorciam as leis criadas pelos monarcas a fim de garantir que seus interesses prevalecessem. ${ }^{43}$

Como os juízes não eram bem vistos pela sociedade pelo fato de manipularem as disposições legais e tirarem vantagem do exercício de suas funções, a Revolução Francesa buscou garantir que houvesse a limitação de seus poderes. Foi criado, inclusive, um tribunal especifico para vigiar as decisões tomadas pelo Poder Judiciário. Esse tribunal foi chamado de Tribunal de Cassação que tinha como objetivo perseguir decisões judiciais que extrapolassem ao que estava disposto no texto da lei. ${ }^{44}$

É nítido que um Poder extremamente limitado, como se buscou fazer com o Poder Judiciário pós- revolução, geraria uma ineficiência da função jurisdicional a ser desenvolvida. Assim, diante da necessidade de interpretar normas contraditórias ou imprecisas, foi criado o instituto do refere législatif, que consistia em uma possibilidade de o juiz solicitar ao Poder Legislativo a interpretação de determinado dispositivo que houvesse gerado dificuldade de interpretação. ${ }^{45}$ Contudo, ainda que o juiz pudesse solicitar que o Corpo Legislativo interpretasse determinada disposição legal, o Poder Judiciário continuava sendo um poder "nulo", visto que ao Corpo Legislativo cabia a criação e, diante de qualquer dificuldade na aplicação da lei, a interpretação das normas; e ao Judiciário cabia apenas os mecanismos para a

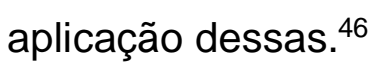

Ainda que a realidade supracitada refira-se a um período pós-revolução e, atualmente, o sistema do civil law utilize de maneira cada vez mais frequente

${ }^{42} \mathrm{O}$ Antigo Regime refere-se originalmente ao sistema social e político aristocrático que foi estabelecido na França. Trata-se principalmente de um regime centralizado e absolutista, em que o poder era concentrado nas mãos do rei. Disponível em <https://pt.wikipedia.org/wiki/Antigo_Regime $\geq$. Acesso em 08 de junho de 2017.

${ }^{43}$ MARINONI, Luiz Guilherme. O STJ enquanto corte de precedentes. Recompreensão do Sistema Processual da Corte Suprema. São Paulo: Editora Revista dos Tribunais, 2013. p. 30. ${ }^{44}$ MARINONI, Luiz Guilherme. O STJ enquanto corte de precedentes. Recompreensão do Sistema Processual da Corte Suprema. São Paulo: Editora Revista dos Tribunais, 2013. p. 31 ${ }^{45}$ MARINONI, Luiz Guilherme. O STJ enquanto corte de precedentes. Recompreensão do Sistema Processual da Corte Suprema. São Paulo: Editora Revista dos Tribunais, 2013. p. 33. ${ }^{46}$ MITIDIERO, Daniel. Precedentes, da persuasão à vinculação. São Paulo: Editora Revista dos Tribunais LTDA, 2016. p. 54. 
jurisprudência, inclusive precedentes, a produção do direito é ainda presa à fonte legal. Contudo, essa fonte legal, a partir dos movimentos constitucionais, é principalmente a constituição, fazendo com que, ainda que a jurisprudência regulamente determinada situação em concreto, esta somente será valida se for congruente com o disposto no texto constitucional ${ }^{47}$

Portanto, a concretização da supremacia da lei no civil law, especificamente no Direito Francês, refletindo na limitação do poder exercido pelos juízes, constituem resultados de um desenvolvimento cultural que visou retirar a interpretação legal da atividade inerente aos juízes e promover uma maior segurança jurídica. A história da supremacia da lei é, segundo Daniel Mitideiro, "a história do encobrimento ideológico do caráter pratico-valorativo da sua interpretação". 48

\subsection{Da mitigação de ambos os sistemas}

A ausência de uma cultura jurídica de respeito aos precedentes, como ocorre no Brasil, está fundada na falsa suposição, muito própria dos sistemas vinculados à civil law, de que a lei seria suficiente para garantir a certeza e a segurança jurídica. Para os adeptos dessa forma de pensar o Direito, a segurança jurídica seria garantida tão-somente pela certeza jurídica advinda da subordinação do juiz à lei. ${ }^{49}$

De acordo com Júlio Cesar Rossi, a distinção de ambos os sistemas como sendo o common law aquele que é caracterizado pela utilização de decisões judiciais precedentes e o civil law aquele em que há uma codificação do ordenamento jurídico tem se tornado cada vez mais inadequada, visto que esses fatores não são mais suficientes para distingui-los. ${ }^{50}$

Tanto na historia do direito francês, quanto na historia do direito inglês, a utilização da codificação do direito e do precedente, respectivamente em cada um desses sistemas, tiveram como objetivo principal o adestramento do poder decorrente

\footnotetext{
${ }^{47}$ ROSSI, Júlio César. Precedente à Brasileira: A Jurisprudência Vinculante no CPC e no Novo CPC. São Paulo: Editora Atlas, 2015. p. 69.

${ }^{48}$ MITIDIERO, Daniel. Precedentes, da persuasão à vinculação. São Paulo: Editora Revista dos Tribunais LTDA, 2016. p. 45.

${ }^{49}$ KREBS, Hélio Ricardo Diniz. Sistemas de Precedentes e Direitos Fundamentais. São Paulo: Editora Revista dos Tribunais LTDA, 2015, p. 79.

${ }^{50}$ ROSSI, Júlio César. Precedente à Brasileira: A Jurisprudência Vinculante no CPC e no Novo CPC. São Paulo: Editora Atlas, 2015. p.70.
} 
do ordenamento jurídico. Assim, em ambos, cada um com seu próprio instrumento, buscou-se alcançar a segurança jurídica e o tratamento igualitário dos jurisdicionados. 51

Muito se fala sobre essa segurança jurídica, contudo, do que ela realmente se trata? De acordo com Daniel Mitideiro, ela é "instrumento que serve à dignidade da pessoa humana e à obtenção da justiça". Justifica-se, portanto, essa constante preocupação dos sistemas em garanti-la, visto que essa é instrumento para obter justiça, o escopo do direito. ${ }^{52}$

Assim, independente de qual ordenamento jurídico tratado, objetiva-se, garantir a que a justiça seja feita, que o bem comum seja alcançado e que a segurança jurídica seja garantida. Portanto, a distinção entre ambos os sistemas se encontra no fato de utilizarem-se instrumentos distintos para 0 alcance desses objetivos delineados. ${ }^{53}$

O common law tem sofrido uma grande influencia do civil law no sentido de trazer codificação ao seu sistema jurídico. O objetivo dessa codificação não é a criação de um novo direito, mas o seu aperfeiçoamento como um todo. Há, inclusive, uma tendência de aplicação do dispositivo legal em face da interpretação trazida pelo common law. Essa aplicação ocorre quando houver conflito entre ambas as fontes, visto que, se a codificação foi criada para aperfeiçoar o direito existente, é razoável que esta prevaleça quando um costume afrontá-la. Assim, possibilita-se a aplicação restritiva do common law em detrimento do disposto no texto da lei. ${ }^{54}$

Diante do exposto, há uma primeira descaracterização do pensamento de que a diferença entre os dois sistemas encontra-se restritivamente na verificação da existência ou não de uma codificação, ou se se utiliza a jurisprudência na construção do direito. ${ }^{55}$

\footnotetext{
${ }^{51}$ MITIDIERO, Daniel. Precedentes, da persuasão à vinculação. São Paulo: Editora Revista dos Tribunais LTDA, 2016. p. 58.

${ }^{52}$ MITIDIERO, Daniel. Precedentes, da persuasão à vinculação. São Paulo: Editora Revista dos Tribunais LTDA, 2016. p..22.

${ }^{53}$ RADBRUCH, Gustav. O Espírito do Direito Inglês e a Jurisprudência Anglo-Americana. Rio de Janeiro: Editora Lumen Juris, 2010. p. 59.

${ }^{54}$ ROSSI, Júlio César. Precedente à Brasileira: A Jurisprudência Vinculante no CPC e no Novo CPC. São Paulo: Editora Atlas, 2015. p..72.

${ }^{55}$ ROSSI, Júlio César. Precedente à Brasileira: A Jurisprudência Vinculante no CPC e no Novo CPC. São Paulo: Editora Atlas, 2015. p. 72.
} 
Da mesma forma que o common law está alargando suas fronteiras e abrangendo codificações e legislações ao seu direito em detrimento do puro judge made law, as jurisprudências e os precedentes assumem destaque cada vez maior nos Países que adotam o sistema jurídico do civil law. Isso ocorre, principalmente, pelo fato de o haver cada vez mais uma constitucionalização do Direito, criando-se a necessidade do estabelecimento de diretrizes jurisprudenciais a fim de que haja o devido respeito à Magna Carta. ${ }^{56}$

Nas palavras de Julio Cesar Rossi, a aproximação de ambos os sistemas decorre de uma consequência lógica decorrente se uma série de fenômenos que começaram a acontecer a partir do fim do século XIX. Esses fenômenos são os seguintes: inicialmente, houve um declínio dos códigos decorrente da elevação das constituições; segundo, surgiram legislações classificadas como especiais caracterizando microssistemas legais; por fim, houve uma ascensão na valorização do direito criado a partir das interpretações judiciais. ${ }^{57}$

A ascensão da valorização das jurisprudências dentro do civil law não é sinônimo de que houve uma desfiguração do sistema. Esse aumento da valorização serve, nas palavras Guido Alpa Georges Abboud, para alcançar os seguintes objetivos: suprimir eventuais contradições, fazer com que seja o texto normativo, fazer com que o direito acompanhe as mutações que ocorrem na sociedade. ${ }^{58}$

Ainda que haja essa ascensão da jurisprudência no sistema do civil law, é importante salientar que esta não é utilizada de maneira discricionária. Seu objetivo é fazer com que o direito seja aplicado naquele determinado caso sob análise, ou seja, que seja aplicada a lei. Assim, a lei é a limitação da jurisprudência nesse sistema. ${ }^{59}$

Durante o desenvolvimento histórico do civil law, houve uma grande influencia dos pensamentos desenvolvidos na "Escola de Exegese", segundo os quais a verdadeira significação do direito somente seria possível obter a partir do texto legal,

\footnotetext{
${ }^{56}$ ROSSI, Júlio César. Precedente à Brasileira: A Jurisprudência Vinculante no CPC e no Novo CPC. São Paulo: Editora Atlas, 2015. p. 72.

${ }^{57} \mathrm{ROSSI}$, Júlio César. Precedente à Brasileira: A Jurisprudência Vinculante no CPC e no Novo CPC. São Paulo: Editora Atlas, 2015. p..75.

${ }^{58}$ ROSSI, Júlio César. Precedente à Brasileira: A Jurisprudência Vinculante no CPC e no Novo CPC. São Paulo: Editora Atlas, 2015. p. 76

${ }^{59}$ ROSSI, Júlio César. Precedente à Brasileira: A Jurisprudência Vinculante no CPC e no Novo CPC. São Paulo: Editora Atlas, 2015. p. 77.
} 
cabendo à interpretação apenas aplicar objetivamente o que estava escrito, independentemente de qualquer juízo de valor. ${ }^{60}$

Contudo, ainda que esse ideal de apenas aplicar a lei pareça, em um primeiro momento, algo simples e objetivo, começou-se a notar que nem sempre o texto legal dispunha daquilo que estava se tratando no caso concreto. Além disso, os casos foram sofrendo mutações e tornando-se cada vez mais complexos, externandose daquilo disposto na lei. Assim, as lacunas que existiam no ordenamento jurídico foram percursoras no reconhecimento da necessidade da função interpretativa, a partir da qual seria possível integrar e aplicar o direito. ${ }^{61}$

Portanto, atualmente, o direito no civil law também vincula o juiz. Houve uma evolução dessa estrutura jurídica, visto que se passou aquela fase em que apenas era permitido ao juiz aplicar a lei, sofrendo a adição de instrumentos como jurisprudências, princípios e doutrina. ${ }^{62}$

A evolução sofrida pelo civil law, conforme anteriormente exposto, teve uma grande influencia dos movimentos constitucionalistas. Isso fez com que a função exercida pelo juiz no civil law se aproximasse daquela exercida pelo juiz no common law. ${ }^{63}$ De acordo com Luiz Guilherme Marinoni:

"O sistema de precedentes, embora desnecessário quando apenas se aplica a lei: é indispensável na jurisdição contemporânea, pois fundamental para outorgar segurança à parte e permitir ao advogado ter consciência de como os juízes estão preenchendo o conceito indeterminado e definindo a técnica processual adequada a certa situação concreta"64

A adesão da jurisprudência pelo sistema jurídico do civil law fez com que se criasse uma abertura para a inclusão dos precedentes nesse. Assim, há mais uma garantia de que os valores inerentes ao Estado de Direito sejam respeitados, visto que

\footnotetext{
60 KREBS, Hélio Ricardo Diniz. Sistemas de Precedentes e Direitos Fundamentais. São Paulo:

Editora Revista dos Tribunais LTDA, 2015, p.114.

${ }^{61}$ KREBS, Hélio Ricardo Diniz. Sistemas de Precedentes e Direitos Fundamentais. São Paulo: Editora Revista dos Tribunais LTDA, 2015, p.116-117.

62 KREBS, Hélio Ricardo Diniz. Sistemas de Precedentes e Direitos Fundamentais. São Paulo:

Editora Revista dos Tribunais LTDA, 2015, p.117-118.

${ }^{63}$ KREBS, Hélio Ricardo Diniz. Sistemas de Precedentes e Direitos Fundamentais. São Paulo:

Editora Revista dos Tribunais LTDA, 2015, p.120.

${ }^{64}$ MARINONI, Luiz Guilherme. Precedentes Obrigatórios. 3. Ed. São Paulo: Ed. RT, 2013.
} 
se aumenta a igualdade do Direito, bem como a dignidade da pessoa humana inserida na sociedade. ${ }^{65}$

Por ser uma figura marcante do sistema do common law, o precedente, quando dentro do civil law é decorrente principalmente das decisões decorrentes dos Tribunais. Assim, um precedente pode ser aquilo que fora decidido em determinada corte e que adquiriu autoridade para casos semelhantes que possam surgir. ${ }^{66}$

É importante salientar que as Cortes Superiores no ambiente do civil law foram criadas com o objetivo de corrigir a interpretação das leis realizadas pelos juízes. Isso ocorreu devido ao fato de a lei, nesse sistema, ser caracterizada como instrumento suficiente para a regulamentação daquilo pelo qual os jurisdicionados passavam. Contudo, essa realidade foi alterada principalmente pelos movimentos constitucionais, visto que passou a ser necessária uma adequação dos sentidos extraídos da lei. ${ }^{67}$

Isso ocorre, pois, um sistema em que cada juiz pronuncia o direito, ou interpreta a lei, de maneira diferente, faz com que seja criada uma insegurança jurídica, visto que não se sabe o que se esperar do Poder Judiciário. Contudo, quando uma Corte Suprema se manifesta, criando um precedente, há uma vinculação de todo o ordenamento jurídico a essa decisão. Ou seja, nem mesmo a própria Suprema Corte poderá tomar uma decisão diferente daquilo que fora previamente firmado. 68

Nas palavras do autor Gilberto Andreassa Junior:

"A jurisdição constitucional diz respeito à atividade jurisdicional do Estado que tem por objeto a tutela as liberdades públicas, consubstanciada nos chamados remédios constitucionais, e também o controle de constitucionalidade das leis e atos normativos instituídos pelo Poder Público, tudo para que sejam observados, de maneira rigorosa, os preceitos constitucionais vigentes." 69

\footnotetext{
${ }^{65}$ MARINONI, Luiz Guilherme. A Ética dos Precedentes, justificativa do novo CPC São Paulo: Editora Revista dos Tribunais LTDA, 2014. p.102.

${ }^{66} \mathrm{ROSSI}$, Júlio César. Precedente à Brasileira: A Jurisprudência Vinculante no CPC e no Novo CPC. São Paulo: Editora Atlas, 2015. p.78.

${ }^{67}$ MARINONI, Luiz Guilherme. Julgamento nas Cortes Supremas: precedente e decisão do recurso diante do novo CPC. São Paulo: Editora Revista dos Tribunais LTDA, 2015. p.17.

68 MARINONI, Luiz Guilherme. A Ética dos Precedentes, justificativa do novo CPC São Paulo: Editora Revista dos Tribunais LTDA, 2014. p..103.

${ }^{69}$ ANDREASSA JUNIOR, Gilberto. Ativismo Judicial e Teoria dos Precedentes. Integração dos

Poderes e Coerência nas Decisões do Judiciário, Curitiba: Juruá Editora, 2015. p.19.
} 
Assim, a unidade garantida pelos precedentes resulta na previsibilidade do ordenamento jurídico. Essa previsibilidade garante a segurança jurídica, visto que o precedente é a revelação daquilo que não fora retirado expressamente da lei, ou seja, transcende a mera interpretação logica. ${ }^{70}$

É nítido, então, que o precedente configura um ordenamento jurídico estável, visto que casos que tiverem alguma semelhança são tratados de maneira igual. Há uma sofisticação do direito previamente positivado. ${ }^{71}$

Diante de todo o exposto, ainda persiste preponderância da lei no sistema do civil law e do precedente no sistema do common law. Contudo, cada vez mais os sistemas tem sofrido mitigação. Essa mitigação é observada inclusive no Brasil, visto que inclusive o Novo Código de Processo Civil buscou garantir que as jurisprudências fossem observadas e respeitadas, visando efetividade e celeridade da justiça. ${ }^{72}$

\section{DO PRECEDENTE NO BRASIL}

\subsection{As marcas do common law no sistema jurídico brasileiro}

Conforme demonstrado no capítulo anterior, os sistemas do common lawe civil law vêm sofrendo uma ascendente mitigação decorrente da constante dinamização do direito. Essa mitigação tem sido influente inclusive no sistema jurídico brasileiro. ${ }^{73}$

Ainda que o Novo Código de Processo Civil tenha dado uma enorme valorização ao sistema utilizado no common law a partir da inclusão expressa em seu texto do respeito às decisões judiciais, a aproximação efetiva entre ambos os sistemas no Brasil ocorreu mais de 10 anos antes da edição deste, com a edição da Emenda Constitucional 45 de 30 de dezembro de $2004 .{ }^{74}$

\footnotetext{
${ }^{70}$ MARINONI, Luiz Guilherme. A Ética dos Precedentes, justificativa do novo CPC São Paulo: Editora Revista dos Tribunais LTDA, 2014. p.103.

${ }^{71}$ MARINONI, Luiz Guilherme. A Ética dos Precedentes, justificativa do novo CPC São Paulo: Editora Revista dos Tribunais LTDA, 2014. p.103.

${ }^{72}$ ROSSI, Júlio César. Precedente à Brasileira: A Jurisprudência Vinculante no CPC e no Novo CPC. São Paulo: Editora Atlas, 2015. p. 78.

${ }^{73}$ ANDREASSA JUNIOR, Gilberto. Ativismo Judicial e Teoria dos Precedentes. Integração dos Poderes e Coerência nas Decisões do Judiciário, Curitiba: Juruá Editora, 2015. p. 27.

${ }^{74}$ ANDREASSA JUNIOR, Gilberto. Ativismo Judicial e Teoria dos Precedentes. Integração dos

Poderes e Coerência nas Decisões do Judiciário, Curitiba: Juruá Editora, 2015. p.27
} 
A Emenda 45 é classificada como aproximação efetiva entre ambos os sistemas, pois, não se pode falar que a aproximação somente se iniciou a partir dela. É possível afirmar que há aproximadamente 20 anos o direito brasileiro tem permitido que fosse encontrada uma obrigatoriedade nos precedentes, com a lei 8.038 de 20 de maio de1990, especificamente em seu artigo 38, que autorizou que os relatores de processos nos órgãos superiores tomassem providencias imediatas. Essas providências consistiam em negar de imediato um recurso nos casos de perda do objeto desses ou quando a sua interposição intempestiva, incabível, improcedente ou contrariasse entendimento dos Tribunais Superiores. ${ }^{75}$

Contudo, não se pode negar que a Emenda Constitucional 45 teve força inovadora no sistema jurídico brasileiro, especificamente no que tange às decisões do Poder Judiciário. A emenda fez com que houvesse a possibilidade de vinculação das decisões proferidas pelos tribunais superiores às instancias inferiores, criando-se o instituto das súmulas vinculantes. Ou seja, ela foi de suma importância para a hierarquização das decisões dentro do âmbito do Judiciário, o que faz com que a aplicação e o uso de um precedente ocorram de maneira mais eficiente e eficaz. ${ }^{76}$

Além da lei 8038 de 1990 e da Emenda Constitucional 45, a mitigação entre os sistemas do civil law e commom law também foi valorizada pelo texto constitucional, o que é um fator extremamente importante para nossa análise, visto que se trata do dispositivo legal constante no topo da pirâmide normativa do sistema jurídico brasileiro. A Constituição Federal prevê que, diante na inexistência de um direito escrito ou devidamente codificado, os juízes podem julgar a lide a partir de princípios existentes na sociedade. Ou seja, foi concedida uma liberdade ao julgador muito próxima daquela existente no sistema do common law. ${ }^{77}$

O progresso na teoria da interpretação do direito, no sistema do civil law, caracterizada pela permuta entre a mera aplicação do disposto na lei para uma busca de sentido ao disposto no texto legal se deu de maneira mais efetiva a partir da

\footnotetext{
${ }^{75}$ DONIZETTI, Elpídio. A força dos Precedentes no Novo Código de Processo Civil. Disponível em:

file://C:/Users/batis/Desktop/MONO/A\%20forca\%20dos\%20precedentes\%20no\%20novo\%20Codigo \%20de\%20Processo\%20Civil.pdf. Acesso em 09 de junho de 2017.

${ }^{76}$ ANDREASSA JUNIOR, Gilberto. Ativismo Judicial e Teoria dos Precedentes. Integração dos Poderes e Coerência nas Decisões do Judiciário, Curitiba: Juruá Editora, 2015. p.27

${ }_{77}$ ANDREASSA JUNIOR, Gilberto. Ativismo Judicial e Teoria dos Precedentes. Integração dos

Poderes e Coerência nas Decisões do Judiciário, Curitiba: Juruá Editora, 2015. p..27
} 
ascendência dos movimentos constitucionalista, conforme exposto no capitulo anterior. Assim, essa função de extração do sentido da lei foi conferida às Cortes Supremas. ${ }^{78}$

De acordo com Marinoni ${ }^{79}$, para que haja uma legitimidade na interpretação da lei dada pela Corte Suprema, além da autoridade trazida por essa, as decisões devem observar um método racional a partir de valorações justificadas. Com isso, o direito deixa de ser mera aplicação do disposto na lei e passa a ser a consolidação da lei somada à interpretação e aos métodos argumentativos. ${ }^{80}$

A utilização de termo jurisprudência advém do Direito Francês, visto ser uma denominação decorrente do sistema do civil law. Assim, é importante ter em mente que as Súmulas foram incluídas no sistema jurídico brasileiro com a finalidade de garantir que o STF pudesse controlar as orientações jurisprudenciais do sistema jurídico nacional. A influencia do common law no direito brasileiro foi efetivamente representada não pela utilização de sumulas ou jurisprudências, mas pela inclusão de um sistema de precedentes obrigatórios vinculantes. ${ }^{81}$

A ideia do precedente é interessante, pois, ao se conferir uma eficácia obrigatória a determinadas decisões, há uma nítida interdependência das funções exercidas pelos Poderes do Estado. Com isso, o Poder Judiciário atua conjuntamente com o Poder Legislativo para que o Direito seja uniforme, e, consequentemente, construído com o fim de garantir igualdade entre os jurisdicionados e uma reflexa segurança jurídica. ${ }^{82}$

Como o Brasil tem passado por uma constante massificação do seu Poder Judiciário, a utilização dos precedentes é vista como uma possível solução desse problema. Essa ideia de solução decorre do fato de que, ao se utilizar um precedente, há uma maior celeridade do julgamento, principalmente quando se trata de demandas

\footnotetext{
${ }^{78}$ MARINONI, Luiz Guilherme. O STJ enquanto corte de precedentes. Recompreensão do Sistema Processual da Corte Suprema. São Paulo: Editora Revista dos Tribunais, 2013. p. 79. ${ }^{79}$ MARINONI, Luiz Guilherme. O STJ enquanto corte de precedentes. Recompreensão do Sistema Processual da Corte Suprema. São Paulo: Editora Revista dos Tribunais, 2013. p. 80. ${ }^{80}$ MARINONI, Luiz Guilherme. O STJ enquanto corte de precedentes. Recompreensão do Sistema Processual da Corte Suprema. São Paulo: Editora Revista dos Tribunais, 2013. p. 80. ${ }^{81}$ MITIDIERO, Daniel. Precedentes, da persuasão à vinculação. São Paulo: Editora Revista dos Tribunais LTDA, 2016. p. 81.

82 MARINONI, Luiz Guilherme. O STJ enquanto corte de precedentes. Recompreensão do Sistema Processual da Corte Suprema. São Paulo: Editora Revista dos Tribunais, 2013. p. 63.
} 
de massa. ${ }^{83} \mathrm{Com}$ isso, o Código de Processo Civil de 2015 buscou entrelaçar as súmulas e jurisprudências com precedentes no ordenamento jurídico Brasileiro, fazendo com que houvesse uma maior influencia das decisões judiciais na formação do direito. ${ }^{84}$

Diante de todo o exposto referente à evolução da teoria de interpretação no Brasil, caracterizada pelo incremento da criação de precedentes ao antigo sistema em que somente se utilizava jurisprudências, são concebidos os seguintes questionamentos: Quando uma decisão deixa de ser jurisprudência e passa a ser um precedente? O que caracteriza uma decisão de Suprema Corte como um precedente?

A resposta aos questionamentos criados está na qualidade da decisão tomada. Ou seja, a decisão de uma Corte Suprema somente adquire caracterização de precedente quando esta busca criar o direito juntamente com o Poder Legislativo. Assim, deve estar intrínseco a essa decisão uma autoridade que permita que elas tenham uma significação dentro do Direito e que garanta que elas sejam respeitadas como precedente..$^{85}$

Como há uma grande probabilidade de diversas teses de direito serem extraídas do mesmo fato, o precedente somente pode ser definido quando se sabe quais os fundamentos jurídicos, os valores envolvidos e as diretrizes de interpretação que se pautaram os juízes para chegar àquela determinada decisão. Ou seja, deve haver uma previa definição de quais ponderações foram levadas em consideração para a elaboração daquele precedente. A ausência da definição desses critérios prejudica a reprodução daquele precedente em questão, haja vista a ratio decidendi da decisão não estar devidamente delineada.. ${ }^{86}$

Portanto, o desenvolvimento do precedente no Brasil traz às decisões tomadas pelo Poder Judiciário a necessidade de preenchimento de requisitos valorativos para que haja a caracterização de uma decisão como precedente. Esses requisitos visam, em suma, fazer com que os critérios utilizados nas decisões sejam

\footnotetext{
${ }^{83}$ ANDREASSA JUNIOR, Gilberto. Ativismo Judicial e Teoria dos Precedentes. Integração dos Poderes e Coerência nas Decisões do Judiciário, Curitiba: Juruá Editora, 2015. p..28

${ }^{84}$ MITIDIERO, Daniel. Precedentes, da persuasão à vinculação. São Paulo: Editora Revista dos Tribunais LTDA, 2016. p. 82.

${ }^{85}$ MARINONI, Luiz Guilherme. O STJ enquanto corte de precedentes. Recompreensão do Sistema Processual da Corte Suprema. São Paulo: Editora Revista dos Tribunais, 2013. p.. 63. ${ }^{86}$ MARINONI, Luiz Guilherme. O STJ enquanto corte de precedentes. Recompreensão do Sistema Processual da Corte Suprema. São Paulo: Editora Revista dos Tribunais, 2013. p. 191.
} 
individualizados, para que se possa extrair as razões daquele precedente criado e concretizar a uniformização do direito. Ou seja, permite-se uma analise baseada na racionalidade para as futuras aplicações daquele precedente. ${ }^{87}$

\subsection{A conceituação do precedente}

Como o precedente é a questão central em debate no presente trabalho, mostra-se essencial a sua conceituação, bem como a diferenciação deste das demais decisões tomadas pelo Poder Judiciário, das Jurisprudências e das Súmulas.

\subsubsection{O precedente, a sua conceituação e a decisão judicial}

Uma decisão judicial é o que gera um precedente, visto que este é fruto da contribuição do Judiciário para a formação do Direito. Contudo, uma decisão judicial tomada sozinha não é sinônimo de criação judicial do precedente Ainda que este derive de uma decisão judicial, por ter uma força vinculante e uniformizadora do Direito, alguns requisitos devem ser preenchidos para que uma decisão se qualifique como um precedente.

Nas palavras de Fredie Didier Junior, o precedente é "a decisão judicial tomada à luz de um caso concreto, cujo núcleo essencial pode servir como diretriz para julgamentos posteriores de casos análogos". ${ }^{88}$ Assim, inicialmente, tem-se que o precedente é extraído do núcleo essencial de uma decisão, havendo uma consequente segmentação da decisão em parte essencial e parte acessória. No common law, essa segmentação se da a partir da classificação das partes da decisão em ratio decidend (núcleo essencial) e em obter dictum (parte acessória).

Em uma segunda avaliação da decisão que gera um precedente, tem-se que esta deve, além de enfrentar a questão fática trazida no caso concreto, fazer uma modulação do direito de acordo com o quadro em análise. Além disso, essa decisão não pode apenas reproduzir um julgado anterior, mas deve buscar uma nova interpretação jurisprudencial sob a ótica daquele novo cenário jurídico. Essa seria

\footnotetext{
${ }^{87}$ MARINONI, Luiz Guilherme. O STJ enquanto corte de precedentes. Recompreensão do Sistema Processual da Corte Suprema. São Paulo: Editora Revista dos Tribunais, 2013. p. 192. ${ }^{88}$ DIDIER JR., Fredie; OLIVEIRA, Rafael; BRAGA, Paula. Curso de direito processual civil. Salvador: Juspodivm, 2013, p. 385
} 
mais uma característica divergente de uma mera decisão judicial e de um precedente. ${ }^{89}$

Sobre esse assunto, Marinoni traz a seguinte ponderação:

"[...] para constituir precedente, não basta que a decisão seja a primeira a interpretar a norma. É preciso que a decisão enfrente todos os principais argumentos relacionados à questão de direito posta na moldura do caso concreto."

"Portanto, uma decisão pode não ter os caracteres necessários à configuração de precedente, por não tratar de questão de direito ou se limitar a afirmar a letra da lei, como pode estar apenas reafirmando 0 precedente." 90

Portanto, conclui-se que, ainda que um precedente decorra de uma decisão judicial, é errônea a afirmação de que qualquer decisão originada no Poder Judiciário é formadora de um precedente.

\subsubsection{O precedente e a jurisprudência}

A jurisprudência é compreendida como um conjunto de decisões judiciais em um mesmo sentido. O Tribunal de Justiça do Distrito Federal dispõe, em seu sítio eletrônico, a seguinte conceituação:

"Jurisprudência é um termo jurídico, que significa o conjunto das
decisões, aplicações e interpretações das leis A jurisprudência pode
ser entendida de três formas, como a decisão isolada de um tribunal
que não tem mais recursos, pode ser um conjunto de decisões
reiteradas dos tribunais, ou as súmulas de jurisprudência, que são as
orientações resultantes de um conjunto de decisões proferidas com
mesmo entendimento sobre determinada matéria." 91

Por mais que, em uma primeira análise, seja comum tratar o precedente como sinônimo de jurisprudência, esses dois são diferentes. A jurisprudência é relacionada à atividade de interpretar a lei. Assim, sua uniformidade é gerada a partir

\footnotetext{
${ }^{89}$ MARINONI, Luiz Guilherme. Precedentes obrigatórios. 3. ed. São Paulo: Revista dos Tribunais, 2013, p.214.

90 MARINONI, Luiz Guilherme. Precedentes obrigatórios. 3. ed. São Paulo: Revista dos Tribunais, 2013, p.214.

${ }^{91}$ DISTRITO FEDERAL. Tribunal de Justiça do Distrito Federal e Territórios. jurisprudência $\mathbf{x}$ precedente. Disponível em: <http://www.tjdft.jus.br/institucional/imprensa/direito-facil/jurisprudenciax-precedente>. Acesso em 13 de junho de 2017.
} 
de várias decisões tomadas em um mesmo sentido, criando-se, inclusive, uma força vinculante nessas. ${ }^{92}$

Para que se tenha uma jurisprudência, é imprescindível que haja um conjunto de decisões em um mesmo sentido. Essa é uma das divergências em relação ao precedente, pois, para que se tenha um precedente, basta uma decisão em um caso concreto, sendo irrelevante o fato de se configurar uma decisão isolada sobre aquele assunto. ${ }^{93}$

Além disso, quando se fala em precedente, fala-se de uma decisão em um caso concreto. Já quando se fala de jurisprudência, tem-se uma pluralidade de decisões. Há, ainda, outra diferença, caracterizada como qualitativa. Essa segunda diferença diz respeito ao conteúdo da decisão. Enquanto o precedente fornece uma regra que pode ser aplicada em casos sucessivos, a jurisprudência trata-se do direito extraído de um caso e aplicado em outro sem nenhuma similaridade fática. ${ }^{94}$

Portanto, ainda que o NCPC tenha conferido uma maior força às jurisprudências, a partir da força vinculante nos julgamentos repetitivos e nos decorrentes de incidente de assunção de competência, o precedente ainda possui uma força maior, visto que ele traz a ultima palavra da administração judiciaria a respeito da questão tratada. Ou seja, enquanto o precedente possui uma autoridade formalmente vinculante em sua natureza, as jurisprudências não a trazem. ${ }^{95}$

\subsubsection{O precedente e as súmulas}

As súmulas são instrumentos utilizados pelas Cortes Superiores para garantir a uniformização das jurisprudências. O autor Cassio Scarpinella Bueno conceitua as Súmulas da seguinte forma:

"As chamadas 'súmulas' são a cristalização de entendimentos jurisprudenciais que predominam nos Tribunais em certo espaço de

\footnotetext{
92 MITIDIERO, Daniel. Precedentes, da persuasão à vinculação. São Paulo: Editora Revista dos Tribunais LTDA, 2016. p. 102.

${ }^{93}$ DISTRITO FEDERAL. Tribunal de Justiça do Distrito Federal e Territórios. jurisprudência $\mathbf{x}$ precedente. Disponível em: <http://www.tjdft.jus.br/institucional/imprensa/direito-facil/jurisprudenciax-precedentes. Acesso em 13 de junho de 2017.

${ }^{4}$ KREBS, Hélio Ricardo Diniz. Sistemas de Precedentes e Direitos Fundamentais. São Paulo: Editora Revista dos Tribunais LTDA, 2015. p.128.

${ }^{95}$ MITIDIERO, Daniel. Precedentes, da persuasão à vinculação. São Paulo: Editora Revista dos Tribunais LTDA, 2016. p. 102.
} 
tempo. A palavra quer indicar as decisões reiteradamente proferidas em determinado sentido pelos Tribunais"96

O NCPC trouxe uma alteração nas Súmulas, visto que antes desse código elas eram vistas apenas como meio de facilitação da jurisdição a ser exercida pelos magistrados (ou seja, sua finalidade se restringia aos juízes, podendo sua elaboração ser feita inclusive de forma mais abrangente). Após o Código de Processo Civil de 2015, as Súmulas passaram a ser tratadas como direcionadoras da interpretação do direito, cabendo a essas a apropriação dos fatos concretos sob análise com aqueles que incitaram a sua criação. ${ }^{97}$

Ainda que as Súmulas sejam instrumentos de uniformização, é comum que as próprias Cortes prolatoras delas as descumpram. Assim, o a coerência do direito não é garantida pela sua elaboração. Diferentemente é o que ocorre com o precedente, que busca trazer uma delimitação do direito a partir do estabelecimento de uma ratio decidendi. Enquanto o precedente busca cristalizar e uniformizar o direito, a súmula se contenta com o mero resumo do dispositivo. ${ }^{98}$

Assim, Marinoni sintetiza a questão da seguinte forma:

"Em suma, o repertório de súmulas se transformou num mero 'guia de interpretação', sem qualquer correspondência com os casos de onde afloraram e com a própria prática do direito jurisprudencial. Transformou-se, melhor dizendo, num 'guia de interpretação estático' e sem qualquer compromisso com o desenvolvimento do direito e com a realização da justiça nos casos concretos"99

Diante do exposto, é nítida a diferença entre uma súmula e um precedente, também se caracterizando errôneo tratamento de ambos como se sinônimos fossem, visto que as Súmulas não geram a vinculação obrigatória de seu conteúdo assim como gera o precedente.

\footnotetext{
${ }^{96}$ BUENO, Cassio Scarpinella. Curso sistematizado de direito processual civil: Recursos. Processos e incidentes nos Tribunais. Sucedâneos recursais: técnicas de controle das decisões jurisdicionais. 2. ed. São Paulo: Saraiva, 2010. Vol. 5, p. 415.

${ }^{97}$ MITIDIERO, Daniel. Precedentes, da persuasão à vinculação. São Paulo: Editora Revista dos Tribunais LTDA, 2016. p. 102.103.

${ }_{98}$ ANDREASSA JUNIOR, Gilberto. Os "Precedentes" no Sistema Jurídico Brasileiro (STF E STJ). Disponível em: < http://andreassaeandreassa.adv.br/wp-content/uploads/2013/09/Os-precedentes-noBrasil-STF-e-STJ.pdf> Acesso em: 08 dez. 2016.

${ }^{99}$ MARINONI, Luiz Guilherme. Precedentes obrigatórios. 2. ed. São Paulo: Revista dos Tribunais, 2011, p.485.
} 


\subsubsection{As súmulas vinculantes}

O instituto da Súmula Vinculante foi introduzido no ordenamento jurídico brasileiro a partir da Emenda Constitucional no .45 de 2004. Este instituto encontra-se disposto no artigo 103-A da Constituição Federal:

"Artigo 103-A : o Supremo Tribunal Federal poderá, de ofício ou por provocação, mediante decisão de dois terços dos seus membros, após reiteradas decisões sobre matéria constitucional, aprovar súmula que, a partir de sua publicação na imprensa oficial, terá efeito vinculante em relação aos demais órgãos do Poder Judiciário e à administração pública direta e indireta, nas esferas federal, estadual e municipal, bem como proceder à sua revisão ou cancelamento, na forma estabelecida em lei." 100

Como essas Súmulas são de observação obrigatória em todas as demais decisões tomadas no âmbito do Poder Judiciário, há uma relativização do entendimento de que as Súmulas são um mero direcionamento das interpretações judiciais.

Contudo, ainda assim, há uma grande diferença dessas em relação aos precedentes. Um enunciado formado a partir de uma Súmula Vinculante tende a estagnar o direito, visto que poucas são as pessoas que podem propor a alteração do disposto em uma súmula vinculante, bem como não há nenhuma formalidade especifica que deva ser respeitada para formular o entendimento jurídico decorrente dessa. ${ }^{101}$

Com essa ausência de formalidade especifica na sua aplicação e formulação, a diferenciação entre a Súmula Vinculante e o Precedente se torna evidente. $O$ entendimento decorrente do precedente é evidentemente relacionado aos fatos que o ensejaram, enquanto na Súmula essa realidade não acontece. Além disso, as fundamentações das Súmulas Vinculantes no Brasil muitas vezes carecem de devida fundamentação ou são tomadas pela decisão de um único caso, afrontando a

\footnotetext{
${ }^{100}$ BRASIL. Constituição (1988). Constituição Federal da República Federativa do Brasil de 1988. Disponível em: <http://www.planalto.gov.br/ccivil_03/Constituicao/Constituicao.htm>. Acesso em 13 de junho de 2017.

101 ANDREASSA JUNIOR, Gilberto Os "Precedentes" No Sistema Jurídico Brasileiro (STF E STJ). Disponível em: < http://andreassaeandreassa.adv.br/wp-content/uploads/2013/09/Os-precedentes-noBrasil-STF-e-STJ.pdf> Acesso em: 08 dez. 2016.
} 
necessidade de reiteradas decisões disposta no artigo 103-A da Constituição Federal. 102

Portanto, é nítida a necessidade de desenvolvimento do instituto da Súmula Vinculante no Direito Brasileiro para que essa se torne tão eficaz quanto o precedente é no sistema jurídico do common law. Isso ocorre, pois, o precedente, para chegar na sua atual realidade, percorreu por muitos anos de aperfeiçoamento dentro do common law, enquanto essas Súmulas se mostram uma novidade jurídica dentro do ordenamento jurídico nacional. ${ }^{103}$

\subsection{A função do precedente no Código de Processo Civil de 2015}

Conforme tudo que fora exposto até o presente momento, as súmulas, as jurisprudências e os precedentes demonstram soluções propostas pelo direito nacional na busca de segurança jurídica a partir de decisões vinculantes. Assim, o objetivo primordial do Novo Código de Processo Civil, no que tange a esse assunto, foi atear os três institutos a fim de que seja garantida uma tutela jurisdicional mais célere. ${ }^{104}$

O autor Daniel Mitideiro divide a sistematização da experiência jurídica brasileira em três momentos, conforme a seguir exposto:

"Tendencialmente, é possível sistematizar a experiência jurídica
brasileira a respeito do tema em três grandes momentos: i) o da busca
pela uniformidade do direito mediante técnicas repressivas; ii) o da
busca pela uniformidade do direito mediante técnicas repressivas e
preventivas; e iii) o da busca pela unidade do direito mediante técnicas
preventivas e repressivas. Cada um desses momentos teve à sua
base uma diferente concepção a respeito da interpretação do direito:
i) a uma, uma teoria cognitivista que visava à declaração da norma
preexistente correta para a solução do caso concreto; ii) a duas, uma
teoria cognitivista que visava à extração da norma preexistente e justa
para solução do caso concreto; e iii) a três, uma teoria adscritivista que
visa à outorga de sentido a textos e a elementos não textuais da ordem

102 ANDREASSA JUNIOR, Gilberto OS "PRECEDENTES" NO SISTEMA JURÍDICO Brasileiro (STF E STJ). Disponível em: < http://andreassaeandreassa.adv.br/wp-content/uploads/2013/09/Osprecedentes-no-Brasil-STF-e-STJ.pdf> Acesso em: 08 dez. 2016.

${ }^{103}$ ANDREASSA JUNIOR, Gilberto Os "Precedentes" No Sistema Jurídico Brasileiro (STF E STJ). Disponível em: < http://andreassaeandreassa.adv.br/wp-content/uploads/2013/09/Osprecedentes-no-Brasil-STF-e-STJ.pdf> Acesso em: 08 dez. 2016.

${ }^{104}$ MITIDIERO, Daniel. Precedentes, da persuasão à vinculação. São Paulo: Editora Revista dos Tribunais LTDA, 2016. p. 82. 
jurídica para prolação de uma decisão justa e para a promoção da unidade do direito." 105

Assim, podemos concluir que o desenvolvimento do precedente no Brasil nasce a partir da busca pela uniformidade do direito, com a utilização de técnicas de repressão, e se arremata na busca pela unidade do direito, somando-se à esta técnica de repressão a utilização de técnicas preventivas. ${ }^{106}$

Vale salientar que, no texto, o autor traz os termos uniformidade e unidade com significações diferentes. Concluímos que a uniformidade é a identidade ou semelhança entre as decisões, enquanto a unidade é algo mais concreto, referindose ao estado de ser uno. Há, portanto, um claro desenvolvimento da teoria do precedente ao longo da historia, visto que o direito brasileiro tem buscado uma padronização mais rígida de suas decisões. ${ }^{107}$

Pode-se concluir que a função precípua das Cortes Superiores não se restringe à uniformização do direito, visto que o "uniformizar" pressupõe a existência de algo que não seja uno, cabendo essa função às Cortes de Justiça, que tem o dever de aplicar isonomicamente o direito a cada caso concreto. Cabem a essas Cortes Superiores, portanto, conceder unidade ao direito e isso somente é possível a partir da análise de casos concretos que possam servir de modelo para solução de casos futuros pelos demais membros do Judiciário. ${ }^{108}$

O Código de Processo Civil de 2015 tem, como traço característico, o fato de a introdução de métodos para que o direito seja mais uniforme. Assim, esse Código é considerado um Código diferenciado, visto que sua base teórica é a busca pela unidade do Direito. ${ }^{109}$

Com isso, é nítida, em seu texto, uma expressa obrigatoriedade de os Tribunais Superiores unificarem esse direito, buscando a efetivação da igualdade

\footnotetext{
105 MITIDIERO, Daniel. Precedentes, da persuasão à vinculação. São Paulo: Editora Revista dos Tribunais LTDA, 2016. p. 82.

${ }^{106}$ MITIDIERO, Daniel. Precedentes, da persuasão à vinculação. São Paulo: Editora Revista dos Tribunais LTDA, 2016. p. 82.

107 MITIDIERO, Daniel. Precedentes, da persuasão à vinculação. São Paulo: Editora Revista dos Tribunais LTDA, 2016. p. 82.

108 MITIDIERO, Daniel. Precedentes, da persuasão à vinculação. São Paulo: Editora Revista dos Tribunais LTDA, 2016. p. 93.

${ }^{109}$ MITIDIERO, Daniel. Precedentes, da persuasão à vinculação. São Paulo: Editora Revista dos Tribunais LTDA, 2016. p. 85.
} 
entre os jurisdicionados e uma consequente segurança jurídica dentro do ordenamento jurídico como um todo. Os precedentes são um dos objetos para a concretização da busca por essa unidade. ${ }^{110}$

Toda essa tentativa de uniformidade do direito, a partir do Novo Código de Processo Civil, é justificada pelo fato de, conforme amplamente debatido ao longo desse trabalho, a interpretação do Direito não decorrer mais de uma mera aplicação do disposto no texto legal. Ainda que objetivo principal da interpretação judicial, no civil law clássico, fosse a mera aplicação da lei ao caso concreto, essa não é a realidade vivida pelo ordenamento jurídico brasileiro. ${ }^{111}$

A interpretação tem se mostrado uma extração empírica do sentido legal, em que ao Judiciário contribui com o Legislativo na sintetização do Direito, a fim de que os jurisdicionados tenha consciência daquilo que está sendo disposto em suas realidades forenses. O Código em questão buscou priorizar métodos preventivos de interpretação em detrimento de métodos repressivos, visando criar uma consciência de necessidade de unidade, pois, unidade é visto como segurança jurídica. ${ }^{112}$

Portanto, o Direito tem se mostrado cada vez mais dinâmico, principalmente no Brasil, que é o objeto do nosso estudo. Não basta que algum direito seja codificado para que haja a concretização desse Direito. É necessário que haja, além do texto legal, uma conjugação deste com a interpretação judicial e com as disposições doutrinárias. ${ }^{113}$

\subsubsection{Institutos caracterizadores do precedente no Novo Código de Processo Civil}

As disposições caracterizadoras do precedente no Novo Código de Processo Civil encontram-se dispostas no capítulo XIII do respectivo código, intitulado "Da sentença e da coisa julgada". ${ }^{114}$

\footnotetext{
110 MITIDIERO, Daniel. Precedentes, da persuasão à vinculação. São Paulo: Editora Revista dos Tribunais LTDA, 2016. p. 85.

${ }_{111}$ MITIDIERO, Daniel. Precedentes, da persuasão à vinculação. São Paulo: Editora Revista dos Tribunais LTDA, 2016. p. 85.

112 MITIDIERO, Daniel. Precedentes, da persuasão à vinculação. São Paulo: Editora Revista dos Tribunais LTDA, 2016. p. 85.

${ }_{113}$ MITIDIERO, Daniel. Precedentes, da persuasão à vinculação. São Paulo: Editora Revista dos Tribunais LTDA, 2016. p. 86.

${ }^{114}$ BRASIL. Lei 13.105 de 16 de março de 2015. Disponível em: <http://www.planalto.gov.br/ccivil_03/_Ato2015-2018/2015/Lei/L13105.htm>. Acesso em 14 de junho de 2017.
} 
A seção II desse capítulo XIII traz os elementos necessários de uma sentença judicial, que são: relatório, dispositivo e fundamento. O Código enumera, no parágrafo primeiro do artigo 489, possíveis elementos da fundamentação de uma decisão judicial que descaracterizam a fundamentação, conforme se vê:

"Art 489 - [...]
§ 1 o Não se considera fundamentada qualquer decisão judicial, seja
ela interlocutória, sentença ou acórdão, que:
I - se limitar à indicação, à reprodução ou à paráfrase de ato normativo,
sem explicar sua relação com a causa ou a questão decidida;
II - empregar conceitos jurídicos indeterminados, sem explicar o
motivo concreto de sua incidência no caso;
III - invocar motivos que se prestariam a justificar qualquer outra
decisão;
IV - não enfrentar todos os argumentos deduzidos no processo
capazes de, em tese, infirmar a conclusão adotada pelo julgador;
V - se limitar a invocar precedente ou enunciado de súmula, sem
identificar seus fundamentos determinantes nem demonstrar que o
caso sob julgamento se ajusta àqueles fundamentos;
VI - deixar de seguir enunciado de súmula, jurisprudência ou
precedente invocado pela parte, sem demonstrar a existência de
distinção no caso em julgamento ou a superação do entendimento."115

Percebe-se que o legislador, ao trazer em seus incisos $\mathrm{V}$ e $\mathrm{VI}$ a necessidade de fundamentação de uma decisão quando da utilização de uma súmula ou precedente, bem como da inutilização desses elementos uniformizadores da decisão judicial, buscou garantir que as decisões fossem devidamente julgadas. Com isso, evitou-se que os juízes utilizassem esses dispositivos como forma de deixar de enfrentar os argumentos jurídicos trazidos ao processo.

Conforme já demonstrado ao longo desse trabalho, o instituto do precedente não "engessa" o direito, pois é possível a superação deste com o passar do tempo e com o desenvolvimento da sociedade. Dentre as técnicas trazidas, vale lembrar as do distinguishing e do overruling. $\mathrm{O}$ overruling tem a função de superar 0 precedente que vem sendo utilizado no Direito, demonstrando sua incongruência com a realidade jurídica vivida pela sociedade. Já o distinguishing tem a função de mostrar que o caso enfrentado no julgamento atual não tem semelhança com o caso que fora

\footnotetext{
${ }^{115}$ BRASIL. Lei 13.105 de 16 de março de 2015. Disponível em: <http://www.planalto.gov.br/ccivil_03/_Ato2015-2018/2015/Lei/L13105.htm>. Acesso em 14 de junho de 2017.
} 
enfrentado no momento da formulação do precedente, afastando a possibilidade de aplicação do precedente no caso concreto. ${ }^{116}$

No Código de Processo Civil de 2015, quando o legislador traz que o juiz deve fundamentar a não aplicação de um determinado precedente, bem como demonstrar a existência de distinção no caso em julgamento, é nítida a tentativa de inclusão do distinguishing. Esse instituto, ainda no sistema do common law, deve passar por um procedimento rigoroso, em que se confronta os casos analisados, evitando que os precedentes percam sua força vinculante. Assim, também buscou-se garantir essa "rigorosidade" da não aplicação de um precedente também dentro do ordenamento jurídico brasileiro. ${ }^{117}$

Com isso, encontramos a primeira caracterização do precedente no ordenamento jurídico brasileiro, visto que a necessidade de fundamentação das decisões judiciais já se mostra característica elementar do sistema de precedentes judiciais.

\subsubsection{Da uniformização da jurisprudência}

Uma das características marcantes do Código de Processo Civil de 2015 foi a tentativa de uniformização da jurisprudência. Assim, está expressamente disposto em seu texto que os tribunais devem buscar a uniformização de sua jurisprudência, conforme a seguir exposto:

Art. 926. Os tribunais devem uniformizar sua jurisprudência e mantêla estável, íntegra e coerente.

$\S 1$ ㅇ Na forma estabelecida e segundo os pressupostos fixados no regimento interno, os tribunais editarão enunciados de súmula correspondentes a sua jurisprudência dominante.

$\S 2$ - Ao editar enunciados de súmula, os tribunais devem ater-se às circunstâncias fáticas dos precedentes que motivaram sua criação. ${ }^{118}$

Como forma de garantia de que os próprios tribunais vão uniformizar sua jurisprudência, o Código dispôs essa uniformização como uma obrigatoriedade.

\footnotetext{
${ }^{116}$ MITIDIERO, Daniel. Precedentes, da persuasão à vinculação. São Paulo: Editora Revista dos Tribunais LTDA, 2016. p. 101.

117 MITIDIERO, Daniel. Precedentes, da persuasão à vinculação. São Paulo: Editora Revista dos

Tribunais LTDA, 2016. p. 101.

${ }^{118}$ BRASIL. Lei 13.105 de 16 de março de 2015. Disponível em:

<http://www.planalto.gov.br/ccivil_03/_Ato2015-2018/2015/Lei/L13105.htm>. Acesso em 14 de junho de 2017.
} 
Assim, busca-se a uniformização, bem como a estabilização e a coerência das decisões judiciais.

Para que essa obrigatoriedade de uniformização de jurisprudência seja respeitada, o código estabeleceu uma espécie de "roteiro", em que os juízes e tribunais devem ser pautar para garantir a efetividade do disposto no Código. O artigo 927 traz o seguinte:

Art. 927. Os juízes e os tribunais observarão:

I - as decisões do Supremo Tribunal Federal em controle concentrado de constitucionalidade;

II - os enunciados de súmula vinculante;

III - os acórdãos em incidente de assunção de competência ou de resolução de demandas repetitivas e em julgamento de recursos extraordinário e especial repetitivos;

IV - os enunciados das súmulas do Supremo Tribunal Federal em matéria constitucional e do Superior Tribunal de Justiça em matéria infraconstitucional;

V - a orientação do plenário ou do órgão especial aos quais estiverem vinculados.

$\S 1$ ㅇ Os juízes e os tribunais observarão o disposto no art. 10 e no art. $\underline{489, \S 10}$, quando decidirem com fundamento neste artigo.

$(\ldots)$

$\S 5^{\circ}$ Os tribunais darão publicidade a seus precedentes, organizandoos por questão jurídica decidida e divulgando-os, preferencialmente, na rede mundial de computadores. ${ }^{119}$

A disposição de que cabe aos tribunais dar publicidade aos seus precedentes demonstra a importância desde no ordenamento jurídico atual. Além disso, ao estabelecer, de maneira imperativa, que os juízes e tribunais devem observar as decisões dos Tribunais Superiores, bem como as Súmulas Vinculantes e orientações jurisprudenciais, há uma concretização na busca pela uniformização jurisprudencial.

Com base em todo o disposto no Código, é possível concluir que, ainda que um juiz tenha uma interpretação do direito divergente daquilo estabelecido pelas Cortes Superiores, ele deve abrir mão de seu entendimento em prol da unidade do Direito.

\footnotetext{
119 BRASIL. Lei 13.105 de 16 de março de 2015. Disponível em: <http://www.planalto.gov.br/ccivil_03/_Ato2015-2018/2015/Lei/L13105.htm>. Acesso em 14 de junho de 2017.
} 
Por fim, toda essa discussão acerca da unidade do Direito faz com que os a importância dos precedentes seja disseminada e reconhecida em todo 0 ordenamento jurídico nacional, visto que se torna essencial o conhecimento destes por todos aqueles que operam o Direito.

\subsubsection{Da possibilidade de alteração de entendimento jurisprudencial}

Assim como no sistema do common law, o Código de Processo Civil de 2015 buscou garantir a dinamização do Direito. Conforme amplamente debatido no presente trabalho, a utilização de precedentes, bem como a tentativa de unidade do direito, não é uma limitação das mutações que sofrem a sociedade, mas uma garantia de segurança jurídica para os jurisdicionados.

A disposição sobre a possibilidade de alteração dos entendimentos jurisprudenciais se encontra nos parágrafos finais do artigo 927 do CPC:

Art. 927: [...]

$\S 20$ A alteração de tese jurídica adotada em enunciado de súmula ou em julgamento de casos repetitivos poderá ser precedida de audiências públicas e da participação de pessoas, órgãos ou entidades que possam contribuir para a rediscussão da tese.

$\S 3$ ㅇ...]

$\S 4$ - A modificação de enunciado de súmula, de jurisprudência pacificada ou de tese adotada em julgamento de casos repetitivos observará a necessidade de fundamentação adequada e específica, considerando os princípios da segurança jurídica, da proteção da confiança e da isonomia. ${ }^{120}$

É nítido que o legislador buscou garantir a cautela na alteração do entendimento dos tribunais, principalmente quando dispôs que essas modificações poderão ser precedidas de audiências publicas e participação de pessoas e órgãos para contribuição na rediscussão das teses.

Essa burocracia na alteração do entendimento de um precedente também é prevista no common law ${ }^{121}$. Assim, o legislador visa garantir que um precedente

\footnotetext{
${ }^{120}$ BRASIL. Lei 13.105 de 16 de março de 2015. Disponível em: <http://www.planalto.gov.br/ccivil_03/_Ato2015-2018/2015/Lei/L13105.htm>. Acesso em 14 de junho de 2017.

121 MITIDIERO, Daniel. Precedentes, da persuasão à vinculação. São Paulo: Editora Revista dos Tribunais LTDA, 2016. p. 101.
} 
corresponda com a realidade social, garantindo a eficácia deste no ordenamento jurídico brasileiro.

\subsubsection{Da modulação dos efeitos da alteração de um entendimento jurisprudencial}

Ainda no cerne da alteração de entendimento jurisprudencial e de interpretação do precedente, o Código trouxe o instituto da modulação de efeitos de uma decisão judicial. Esse instituto tem como objetivo principal a garantia da segurança jurídica.

O instituto está previsto no § 3o do artigo 927 do Código de Processo Civil:

Art. 927: [...]

$\S 30 \mathrm{Na}$ hipótese de alteração de jurisprudência dominante do Supremo Tribunal Federal e dos tribunais superiores ou daquela oriunda de julgamento de casos repetitivos, pode haver modulação dos efeitos da alteração no interesse social e no da segurança jurídica. ${ }^{122}$

A alteração de entendimentos firmados em precedentes é completamente viável no sistema jurídico atual. Como a segurança jurídica é o objetivo central de todo o sistema de precedentes, essa não pode ser sacrificada pela alteração desses entendimentos.

Ainda que a regra no ordenamento jurídico atual seja a de que a lei vigente rege 0 ato, os tribunais superiores poderão limitar a aplicação dos novos entendimentos para processos futuros, proibindo a retroatividade de suas novas decisões e garantindo que o ordenamento jurídico continue estável.

Portanto, o instituto da modulação de efeitos é influenciado pelo interesse social e visa garantir a segurança jurídica do sistema jurisprudencial, evitando que alterações de interpretação gerem surpresas dentro do ordenamento jurídico. É um instituto que protege o cidadão, evitando mudanças bruscas dentro daquilo que já era esperado da jurisdição.

\footnotetext{
${ }^{122}$ BRASIL. Lei 13.105 de 16 de março de 2015. Disponível em: <http://www.planalto.gov.br/ccivil_03/_Ato2015-2018/2015/Lei/L13105.htm>. Acesso em 14 de junho de 2017.
} 


\subsubsection{O incidente de resolução de demandas repetitivas}

No Capítulo VIII do Código de Processo Civil de 2015, está previsto o incidente de resolução de demandas repetitivas. Esse instituto pode ser considerado fruto do desenvolvimento do precedente no ordenamento jurídico brasileiro, pois visa garantir uma uniformização da jurisprudência em causas que contem a mesma matéria de direito.

O artigo 976 traz o cabimento do referido instituto:

Art. 976. É cabível a instauração do incidente de resolução de demandas repetitivas quando houver, simultaneamente:

I - efetiva repetição de processos que contenham controvérsia sobre a mesma questão unicamente de direito;

II - risco de ofensa à isonomia e à segurança jurídica. ${ }^{123}$

Em suma, o referido instituto ocorre quando houver processos que envolvam matéria repetitiva de matéria de direito em mesma Região ou Estado. Assim, o incidente de que trata essa matéria será levado ao presidente do respectivo Tribunal e, se for admitida a matéria incidente, todos os processos que possuam a mesma matéria no Estado ou na Região terão seus efeitos suspensos.

De acordo com o Código, esse incidente deverá ser julgado em até 1 ano de sua instauração e terá preferencia sobre todos os demais feitos. Além disso, ao ser julgado o incidente, a tese jurídica será aplicada a todos os processos (individuais ou coletivos) que versem sobre matéria idêntica de direito e aos casos futuros, também com questão de direito idêntica, que vierem a tramitar no território de competência do tribunal. ${ }^{124}$

Portanto, como a decisão tomada em incidente de resolução de demanda repetitiva vinculará o primeiro grau de jurisdição e o próprio tribunal, essa decisão é tratada como um precedente, visto que será guia para os processos estão em tramitação e os que virão a tramitar naquele Estado ou Região.

\footnotetext{
${ }^{123}$ BRASIL. Lei 13.105 de 16 de março de 2015. Disponível em: <http://www.planalto.gov.br/ccivil_03/_Ato2015-2018/2015/Lei/L13105.htm>. Acesso em 14 de junho de 2017.

${ }^{124}$ BRASIL. Lei 13.105 de 16 de março de 2015. Disponível em: <http://www.planalto.gov.br/ccivil_03/_Ato2015-2018/2015/Lei/L13105.htm>. Acesso em 14 de junho de 2017.
} 


\section{DA RELAÇÃO DO PRECEDENTE COM O ESTADO DE DIREITOS FUNDAMENTAIS}

\subsection{Da supremacia da constituição resultante na interdependência entre as Funções de Poder}

O incentivo na utilização de precedentes vinculantes no Brasil resulta, consequentemente, em uma proposta diferenciada à lição clássica de separação dos Poderes de Estado propostas por John Locke e Montesquieu nos séculos XVII e XVIII, haja vista consistir em uma colaboração obrigatória entre as diferentes funções exercidas por esses Poderes. ${ }^{125}$

Essa proposta diferenciada de interdependência dos Poderes de Estado surge a partir de uma evolução do Estado de Direito para o Estado de Direitos Fundamentais. A ideia do Estado de Direitos Fundamentais surge a partir de um constitucionalismo contemporâneo, segundo o qual o paradigma do Direito não se encontra espalhado em diversas normas jurídicas, oriundas das mais diferenciadas leis. O paradigma do Direito proposto é a Constituição Federal, a partir de um compromisso crescente com os Direitos e Garantias Fundamentais. ${ }^{126}$

Assim, o constitucionalismo contemporâneo é analisado a partir de três perspectivas, segundo a teoria proposta pela Professora Doutora Christine Oliveira Peter da Silva:

"a) da substituição da ideia de supremacia da lei pela ideia de supremacia da Constituição; b) da transição da teoria da separação de funções do poder para a teoria da interdependência entre as funções de poder; c) da dogmática dos direitos fundamentais como direitos subjetivos para a dogmática dos direitos fundamentais como direito objetivo". ${ }^{127}$

Com isso, a função de um juiz dentro do Estado de Direitos Fundamentais é bem mais complexa e diferenciada da função exercida pelo juiz dentro do Estado de Direitos. Isso ocorre, pois, a sua função deixa de ser a mera interpretação da lei para

\footnotetext{
${ }^{125}$ SILVA, Christine Oliveira Peter da. Estado de Direitos Fundamentais. Disponível em <https://jus.com.br/artigos/42128/estado-de-direitos-fundamentais>.Acesso em 07 de julho de 2017. ${ }^{126}$ SILVA, Christine Oliveira Peter da. Estado de Direitos Fundamentais. Disponível em $<$ https://jus.com.br/artigos/42128/estado-de-direitos-fundamentais>.Acesso em 07 de julho de 2017. ${ }^{127}$ SILVA, Christine Oliveira Peter da. Estado de Direitos Fundamentais. Disponível em <https://jus.com.br/artigos/42128/estado-de-direitos-fundamentais>.. Acesso em 07 de julho de 2017.
} 
a atribuição de sentido a essa a partir de uma análise constitucional. Justifica-se, portanto, a teoria de que uma separação rígida dos Poderes de Estado não é adequada no Estado de Direitos Fundamentais, haja vista uma constante sobreposição e auto ajuste de uma função sobre a outra. ${ }^{128}$

Essa interdependência explica-se, também, pelo fato de haver uma necessidade crescente de que as decisões tomadas pelo Poder Judiciário sejam embasadas nas necessidades sociais. Uma lei, após ser editada, pode tornar-se obsoleta com o passar do tempo e não mais corresponder com a realidade social vivida pela população, uma vez que há constantes mutações e modificações culturais. Assim, o Judiciário colabora com o Legislativo na construção do Direito a partir da atualização deste, tornando, consequentemente, a atuação das Cortes Supremas imprescindíveis, uma vez que cabe a estas atribuir unidade ao Direito e interpretá-lo a partir do disposto na Constituição Federal. ${ }^{129}$

No civil law clássico, plenamente vinculado às codificações, não havia uma preocupação com o fato de estar sendo atribuída igualdade entre os cidadãos diante de uma decisão, pois o que realmente importava era uma igualdade desses cidadãos perante à lei. Diferentemente, no common law, por ter como base fundamental a teoria do stare decisis e, portanto, dos precedentes, há um incentivo constante na produção de igualdade entre os jurisdicionados. ${ }^{130}$

Conclui-se que o sistema de precedentes judiciais obrigatórios está embasado na igualdade de todos perante o Direito. Assim, a teoria do Estado Constitucional é vista como sinônimo de desenvolvimento do Direito pelo fato de incentivar que seja reverenciada a igualdade dentro das relações da sociedade. ${ }^{131}$

Portanto, essa teoria, ao estar presente em um País que, predominantemente, utiliza o sistema do civil law, pode ser vista como instrumento de mitigação entre este sistema e o sistema do common law. O valor que se busca proteger com um sistema de precedentes não é mais a unidade do direito, mas a igualdade de todos os jurisdicionados, decorrente de uma vinculação obrigatória de

\footnotetext{
${ }^{128}$ SILVA, Christine Oliveira Peter da. Estado de Direitos Fundamentais. Disponível em $<$ https://jus.com.br/artigos/42128/estado-de-direitos-fundamentais>.. Acesso em 07 de julho de 2017. ${ }^{129}$ MARINONI, Luiz Guilherme. O STJ enquanto corte de precedentes. Recompreensão do Sistema Processual da Corte Suprema. São Paulo: Editora Revista dos Tribunais, 2013. p. 163. 130 MARINONI, Luiz Guilherme. O STJ enquanto corte de precedentes. Recompreensão do Sistema Processual da Corte Suprema. São Paulo: Editora Revista dos Tribunais, 2013. p. 163. ${ }^{131}$ MARINONI, Luiz Guilherme. O STJ enquanto corte de precedentes. Recompreensão do Sistema Processual da Corte Suprema. São Paulo: Editora Revista dos Tribunais, 2013. p 162.
} 
todos os tribunais e juízes ao Direito tutelado pela Corte Suprema (Direito esse decorrente da análise das mudanças sofridas pela sociedade). ${ }^{132}$

\subsection{Os Direitos Fundamentais e o Processo}

Historicamente, tem-se que a Constituição Federal de 1988 é resultado de uma luta contra o regime militar instaurado no Brasil entre o ano de 1964 ao ano de 1985. Por conta disso, ela é marcada por um renomado desenvolvimento da proteção aos direitos e garantias fundamentais, bem como da consequente concretização legislativa desses direitos. ${ }^{133}$

A Constituição de 1988 foi a primeira a proteger expressamente os direitos fundamentais, inclusive pelo fato de esta ter reservado um capítulo especifico para tratar desse assunto. Além disso, houve o enquadramento do instituto da clausula pétrea no texto constitucional, o que demonstra, mais uma vez, a preocupação com a proteção efetiva dos direitos fundamentais. ${ }^{134}$

Todo esse processo de inclusão desses direitos na Carta Magna impõe, ao Poder Publico, uma atuação de acordo com aquilo que fora imposto pela Constituição, possibilitando uma maior concretização desses direitos. Além disso, possibilita que os jurisdicionados possam cobrar que as atitudes dos governantes sejam de acordo com o que fora determinado pelo texto constitucional. ${ }^{135}$

No que tange à dogmática dos direitos fundamentais, tem-se que a valorização destes resulta de um processo de complexificação da sociedade. Com o desenvolvimento social, passou-se a ter a problemática de que o confronto entre diferentes direitos fundamentais não pudesse ser solucionado como são solucionados tipicamente conflitos normativos. Assim, métodos clássicos não seriam mais efetivos para a satisfação das necessidades jurisdicionais da sociedade. ${ }^{136}$

\footnotetext{
132 MARINONI, Luiz Guilherme. O STJ enquanto corte de precedentes. Recompreensão do Sistema Processual da Corte Suprema. São Paulo: Editora Revista dos Tribunais, 2013. p. 165. ${ }^{133}$ KREBS, Hélio Ricardo Diniz. Sistemas de Precedentes e Direitos Fundamentais. São Paulo: Editora Revista dos Tribunais LTDA, 2015. p..29-30.

${ }^{134}$ KREBS, Hélio Ricardo Diniz. Sistemas de Precedentes e Direitos Fundamentais. São Paulo: Editora Revista dos Tribunais LTDA, 2015. p.42.

${ }^{135}$ KREBS, Hélio Ricardo Diniz. Sistemas de Precedentes e Direitos Fundamentais. São Paulo: Editora Revista dos Tribunais LTDA, 2015. p.42.

${ }^{136}$ SILVA, Christine Oliveira Peter da. Estado de Direitos Fundamentais. Disponível em <https://jus.com.br/artigos/42128/estado-de-direitos-fundamentais>.. Acesso em 07 de julho de 2017.
} 
Os Direitos Fundamentais assumem uma notável posição dentro das Constituições Contemporâneas, uma vez que deixam a sua limitada função de direitos de defesa e passam a assumir a função de princípios, destinados a orientar todos os atos do Estado. ${ }^{137}$ Esse é o momento em que há o destaque da importância dos direitos fundamentais dentro do processo, pois esses não são mais limitados à temática constitucional, mas passaram a adentrar todo o direito, em todas as suas matérias e ramos.

Assim, o neoconstitucionalismo teve como resultado elementar o processo de constitucionalismo do direito como um todo. Decorreu, portanto, em uma essencial irradiação dos direitos fundamentais e dos seus efeitos por todo o ordenamento jurídico. ${ }^{138}$

Com a Constituição passando a ter caráter força jurídica dentro Direito, ela deixa de ter uma função meramente valorativa e assume uma função normatizadora. A partir dessa aderência normativa à Constituição, há o desenvolvimento de uma perspectiva dirigente em seu texto, uma vez que esta passa a incumbir ao Estado a função de concretizar seu conteúdo essencial e, consequentemente, seus direitos fundamentais. ${ }^{139}$

Diante de tudo isso, há de se destacar que o Estado passa a ter função de cumprir esses Direitos Fundamentais, bem como garantir que haja o devido cumprimento desses pelo povo dentro de suas relações privadas. Aqui, entra a importância de medidas estatais positivas para a concretização desses direitos. Portanto, os direitos fundamentais deixam a sua função de direitos subjetivos, inerente no constitucionalismo dos séculos XVIII e XIX, e passam a ter uma função objetiva, haja vista serem fonte de orientação dos atos estatais e privados. ${ }^{140}$

Uma das consequências dessa função objetiva dos Direitos Fundamentais está na interdependência dos poderes, conforme anteriormente apresentado. Isso ocorre, pois, no Estado de Direitos Fundamentais, o que deve ser buscado substancialmente é a concretização do disposto no texto da constituição. Para que

\footnotetext{
137 SILVA, Christine Oliveira Peter da. Estado de Direitos Fundamentais. Disponível em $<$ https://jus.com.br/artigos/42128/estado-de-direitos-fundamentais>.. Acesso em 07 de julho de 2017. 138 KREBS, Hélio Ricardo Diniz. Sistemas de Precedentes e Direitos Fundamentais. São Paulo: Editora Revista dos Tribunais LTDA, 2015. p..68 ${ }^{139}$ SILVA, Christine Oliveira Peter da. Estado de Direitos Fundamentais. Disponível em <https://jus.com.br/artigos/42128/estado-de-direitos-fundamentais>.. Acesso em 07 de julho de 2017. ${ }^{140}$ SILVA, Christine Oliveira Peter da. Estado de Direitos Fundamentais. Disponível em <https://jus.com.br/artigos/42128/estado-de-direitos-fundamentais>.Acesso em 07 de julho de 2017.
} 
essa concretização aconteça, há o compartilhamento desta entre todos os Poderes. ${ }^{141}$ Ou seja, o Legislativo passa a legislar a fim de que haja a concretização desses direitos; o Judiciário toma decisões que garantam a aplicabilidade desses Direitos; o Executivo adota medidas a fim de que haja a concretização desses direitos.

Assim, a teoria dos precedentes pode ser considerada um resultado dessa interdependência entre as funções dos Poderes Estatais, pois a segurança jurídica decorrente desse instituto se apresenta como um direito fundamental. É direito dos jurisdicionados saber como estão sendo tomadas as decisões dentro do Poder Judiciário, bem como ter uma possível previsão de se sua lide terá um resultado favorável para aquele que pleiteia ou não.

Ao tomar uma decisão com força de precedente, o Poder Judiciário contribuiu com o Poder Legislativo no processo de unidade do Direito, pois sua decisão passa a ter força normativa e diretiva de todas as futuras decisões a serem tomadas pelo judiciário. É nesse momento que surge a segurança jurídica decorrente do precedente, pois parte-se da premissa de que a linha de raciocínio adotada por determinada decisão servirá de embasamento para a solução de futuras lides que possam surgir na sociedade.

Usufruir de um processo justo é um elemento que integra a dogmática dos Direitos Fundamentais. Essa é a justificativa primordial para a influencia exercida pelos direitos fundamentais dentro do Processo Civil. ${ }^{142}$

O direito a um devido processo legal se apresenta como um direito fundamental pois é caracterizador do direito de acesso à justiça. Assim, é direito dos jurisdicionados obter um provimento judicial que respeite as garantias trazidas pelo sistema, tanto no seu plano jurídico, como no seu plano empírico. ${ }^{143}$

O papel dos Direitos Fundamentais é extremamente elementar dentro do processo, haja vista que incumbe a este orientar na maneira pela qual o processo é conduzido. Essa importância foi detalhadamente estudada dentro do Novo Código de Processo Civil, visto que o legislador, além de garantir que haja a devida ponderação no momento da resolução de conflitos normativos, trouxe um capitulo intitulado "Das

\footnotetext{
${ }^{141}$ SILVA, Christine Oliveira Peter da. Estado de Direitos Fundamentais. Disponível em <https://jus.com.br/artigos/42128/estado-de-direitos-fundamentais $>$.Acesso em 07 de julho de 2017. 142 KREBS, Hélio Ricardo Diniz. Sistemas de Precedentes e Direitos Fundamentais. São Paulo: Editora Revista dos Tribunais LTDA, 2015. p.70.

${ }^{143}$ KREBS, Hélio Ricardo Diniz. Sistemas de Precedentes e Direitos Fundamentais. São Paulo: Editora Revista dos Tribunais LTDA, 2015. p.71.
} 
Normas fundamentais e da aplicação das normas processuais". ${ }^{144}$ Assim, a teoria dos Direitos Fundamentais é um efetivo instrumento de fixação de injustiças sociais. ${ }^{145}$

\subsection{Os Precedentes e os Direitos Fundamentais}

De acordo com o autor Hélio Ricardo Diniz Krebs, a importância dos precedentes dentro do ordenamento jurídico justifica-se pelo fato de estes fortalecerem a segurança jurídica a partir da concessão de uniformidade, estabilidade, previsibilidade e isonomia aos processos judiciais. ${ }^{146}$

Os precedentes, dentro do sistema brasileiro, é diferente daquele decorrente do sistema do common law. Inicialmente, a respeitabilidade obrigatória destes não decorre de uma cultura jurídica , como ocorre na Inglaterra, mas de uma atuação impositiva do Poder Legislativo. Assim, não devemos analisar o precedente brasileiro da mesma forma que se analisa o precedente nos Países de origem anglosaxônicos. ${ }^{147}$

Os sistemas de precedentes que vem se instalando no Brasil possui como base as técnicas utilizadas pelos Tribunais Superiores para uniformização de jurisprudências. Dentre as que foram instituídas nos últimos anos, destacam-se os julgamentos ocorridos nos casos repetitivos e o instituto da repercussão geral, encontrada nos Recursos Extraordinários. ${ }^{148}$

O desenvolvimento do precedente e sua respeitabilidade servem de meios para a concretização de direitos fundamentais. Ainda que isso ocorra indiretamente, é evidente a sua relação com a afirmação desses direitos, uma vez que este instituto reverencia diversos princípios constitucionais, dentre os quais podemos destacar o da segurança jurídica, do devido processo legal, da isonomia e o da dignidade da pessoa humana. ${ }^{149}$

\footnotetext{
${ }^{144}$ KREBS, Hélio Ricardo Diniz. Sistemas de Precedentes e Direitos Fundamentais. São Paulo: Editora Revista dos Tribunais LTDA, 2015. p.76.

${ }^{145}$ KREBS, Hélio Ricardo Diniz. Sistemas de Precedentes e Direitos Fundamentais. São Paulo: Editora Revista dos Tribunais LTDA, 2015. p.77.

${ }^{146}$ KREBS, Hélio Ricardo Diniz. Sistemas de Precedentes e Direitos Fundamentais. São Paulo: Editora Revista dos Tribunais LTDA, 2015. p.258.

${ }_{147}$ KREBS, Hélio Ricardo Diniz. Sistemas de Precedentes e Direitos Fundamentais. São Paulo: Editora Revista dos Tribunais LTDA, 2015. p.185-186.

${ }_{148}$ KREBS, Hélio Ricardo Diniz. Sistemas de Precedentes e Direitos Fundamentais. São Paulo: Editora Revista dos Tribunais LTDA, 2015. p.258.

${ }^{149}$ KREBS, Hélio Ricardo Diniz. Sistemas de Precedentes e Direitos Fundamentais. São Paulo: Editora Revista dos Tribunais LTDA, 2015. p.265-270.
} 
Patrícia Perrone Campos Mello justifica a utilização de um sistema de precedentes vinculantes a partir das vantagens decorrentes deste, que são, segundo a autora, de garantir a segurança jurídica, a isonomia e a eficiência ${ }^{1}$, conforme a segue:

\begin{abstract}
"Entende-se que a adoção de tal sistema promove três valores centrais: a segurança jurídica, a isonomia e a eficiência. A segurança jurídica é assegurada porque a orientação proferida por meio da ratio decidendi tende a ser mais precisa e, portanto, menos genérica que aquela veiculada pela lei, já que é delimitada pelo caso concreto. Esse primeiro aspecto facilitaria a compreensão e o prévio conhecimento do direito pelo jurisdicionado." ${ }^{1}$
\end{abstract}

De acordo com a autora, a isonomia é garantida quando casos semelhantes recebem o mesmo tratamento. Isso é aspecto substancial dos Estados que são caracterizados como democráticos de direito. No que tange a eficiência, ao se ter um precedente formado, a aplicação desse pelos juízes em casos futuros faz com que haja economia de recursos e tempo no momento de elaboração da decisão judicial. 150

No Brasil, há, ainda, uma dificuldade no que tange a respeitabilidade do precedente. Essa dificuldade surge não apenas no momento em que Cortes Inferiores não se subordinam às decisões caracterizadas como vinculantes, mas, também, quando as Cortes Vinculantes não contribuem para a unidade do direito ao proferir a decisão. Essa não contribuição com a cultura do precedente pelas Cortes Superiores ocorre quando as decisões proferidas não são suficientemente claras, consistentes ou devidamente fundamentadas para vincular a decisão de uma Corte Inferior. ${ }^{151}$

Além disso, uma decisão de uma Corte Superior deve ser consistente ao ponto de não ser facilmente alterada pelas conveniências politicas. O precedente deve ser tratado como método para garantia da segurança jurídica, evitando que os precedentes causem um ambiente caótico de decisões que não contribuirão para o desenvolvimento do sistema jurídico. ${ }^{152}$

Portanto, para que o precedente no ordenamento jurídico brasileiro seja tão eficiente como ocorre na Inglaterra, deve ser aperfeiçoado o método decisório dos

\footnotetext{
${ }^{150}$ MELLO, Patrícia Perrone Campos. O Supremo e os precedentes constitucionais: como fica a sua eficácia após o Novo Código de Processo Civil. Universitas JUS, v. 26, n. 2, p. 52, 2015.

${ }_{151}$ MELLO, Patrícia Perrone Campos. O Supremo e os precedentes constitucionais: como fica a sua eficácia após o Novo Código de Processo Civil. Universitas JUS, v. 26, n. 2, p. 52, 2015.

152 MELLO, Patrícia Perrone Campos. O Supremo e os precedentes constitucionais: como fica a sua eficácia após o Novo Código de Processo Civil. Universitas JUS, v. 26, n. 2, p. 52, 2015.
} 
Tribunais Superiores, a fim de que suas decisões tenham um nível superior ao daquelas tomadas pelas instancias inferiores. Assim, essas Cortes Supremas devem entender que a respeitabilidade de suas decisões dependem das suas próprias atuações. ${ }^{153}$

\section{DOS RESULTADOS DA PESQUISA}

\subsection{Da metodologia utilizada}

Na presente pesquisa, foram analisadas decisões da Suprema Corte do Reino Unido e do Supremo Tribunal Federal, referentes aos anos de 2010 a 2015, com o objetivo de comparar o método do precedente judicial em ambos os Países.

Foram utilizadas diversas técnicas de pesquisa para chegar ao resultado da pesquisa. Inicialmente, utilizaram-se pesquisas bibliográficas, uma vez que há uma ampla diversidade bibliográfica pátria dedicada à análise do precedente judicial e, principalmente, ao desenvolvimento deste a partir do Novo Código de Processo Civil.

Além disso, foi realizada uma análise quantitativa, caracterizada pela busca exploratória nos sítios da Corte Suprema Brasileira e a do Reino Unido. No sítio do STF, já se encontra disponível uma lista de casos notórios da Corte. A partir dessa lista, foi realizado um corte temporal referente aos anos de 2010 a 2015 a fim de identificar quais casos tratam tipicamente de concretização de direitos fundamentais (casos jusfundamentais).

$\mathrm{Na}$ pesquisa pelos precedentes da Suprema Corte Inglesa, a pesquisa envolveu a busca por casos julgados entre os anos de 2010 e 2016, buscando-se identificar as temáticas e a classificação dos casos jusfundamentais.

Após essas pesquisas qualitativas e quantitativas, foram analisadas as áreas do direito abrangidas em cada decisão e gerada tabela com os dados quantitativos dos casos tratados como precedentes na Inglaterra. Por fim, buscou-se contato com uma inglesa, estudante de Direito na Inglaterra, para que esta pudesse responder os questionamentos gerados pela pesquisa no que tange à aplicação efetiva do precedente no País e, a partir de suas respostas, chegou-se a conclusões inseridas no texto do presente relatório.

\footnotetext{
${ }^{153}$ MELLO, Patrícia Perrone Campos. O Supremo e os precedentes constitucionais: como fica a sua eficácia após o Novo Código de Processo Civil. Universitas JUS, v. 26, n. 2, p. 52, 2015.
} 


\subsection{Dos resultados referentes aos anos de 2010 a 2015 na Inglaterra}

É importante que seja esclarecida a composição da Suprema Corte do Reino Unido. Esta Corte é composta por doze juízes, que são intitulados Lords e é o mais alto tribunal de Direito da Inglaterra, País de Gales, Irlanda do Norte e Escócia. Ela foi criada pelo Constitutional Reform Act de 2005 e teve seu inicio em primeiro de outubro de 2009.

Dentre os anos de 2010 a 2015, foi catalogado um total de 490 decisões da Suprema Corte do Reino. Cada decisão tomada pela Suprema Corte Inglesa analisa uma área especifica dentro do Direito. Com isso, nesses seis anos, foram encontradas 160 diferentes áreas do Direito Anglo-Saxão. ${ }^{154}$

Das 490 decisões encontradas, foram analisadas as 5 áreas do direito mais prevalentes nesse lapso temporal. Essas 5 áreas foram European Convention on Human Rights (ECHR), Immigration, Employment, Criminal Law e Family Law.

Observaram-se, dentro dessas áreas prevalentes, os seguintes percentuais: ECHR totalizou $11 \%$ das decisões; Immigration totalizou $7,5 \%$ das decisões, Employment totalizou 6\% das decisões, Criminal Law totalizou 3,9\% das decisões e Family Law totalizou 3,2\%. Essas áreas de prevalência somam 31,6\% de todas as decisões da Suprema Corte.

Vejamos:

${ }^{154}$ SUPREME COURT UK. Decides Cases. Dados disponíveis em <https://www.supremecourt.uk/decided-cases>..Acesso em 28 de julho de 2017. 


\section{DECISÕES}

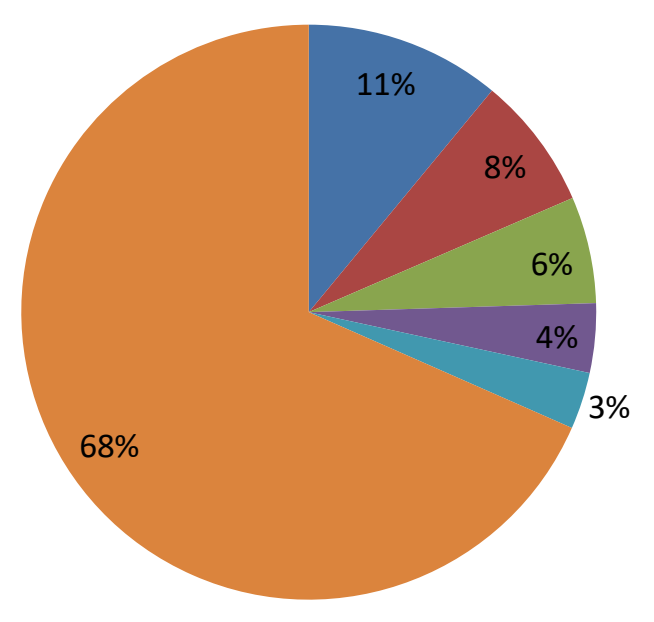

口ECHR

- IMMIGRATION

- EMPLOYMENT

- CRIMINAL LAW

- FAMILY LAW

- OUTRAS

A pesquisa seleciona um caso de cada uma dessas áreas, de maneira aleatória dentro desse lapso temporal de 2010 a 2015, para demonstrar o direito prevalente no desenvolvimento dos precedentes ingleses. O objetivo da análise de cada um desses casos selecionados é fazer com que fiquem evidentes os direitos fundamentais da Inglaterra, sejam aqueles que são semelhantes com o direito fundamental brasileiro, sejam aqueles que são distintos do direito brasileiro pelo fato de ser uma cultura jurídica diferenciada.

A primeira área de prevalência é a que trata da Convenção Europeia de Direitos Humanos. O caso escolhido aleatoriamente é "Beghal (Appellant) v Director of Public Prosecutions (Respondent)", do dia 22 de julho de 2015, perante os Lords Neuberger, Kerr, Dyson, Hughes e Hodge. Nesse julgamento, analisou-se o Ato de Terrorismo de 2000, que, em seu anexo 7, exige que sejam respondidas perguntas realizadas por policiais, agentes de imigração e oficiais da alfandega. Assim, analisou-se as consequências da recusa de resposta confrontadas com os direitos garantidos pela Convenção Europeia para a Proteção dos Direitos Humanos e Fundamentais Liberdades ("CEDH"), e, em particular, os artigos 8ำ (direito ao respeito e a vida familiar), 5 (direito à liberdade) e 6 (privilégio contra autoincriminação). ${ }^{155}$

${ }^{155}$ SUPREME COURT UK. Beghal (Appellant) v Director of Public Prosecutions (Respondent). Disponivel em <https://www.supremecourt.uk/cases/docs/uksc-2013-0243-judgment.pdf $\geq$. Acesso em 30 de julho de 2017. 
A segunda área de prevalência foi sobre imigração. Percebe-se que, o fato de os Países integrantes do Reino Unido ser muito visados pelos migrantes faz com que $o$ assunto seja frequente na Suprema Corte Inglesa. $O$ julgamento sorteado para análise, dentro desse assunto, ocorreu no dia 16 de junho e trata da lei do imigrante. O nome do caso é "MS (Palestinian Territories) (FC) (Appellant) v Secretary of State for the Home Department (Respondent)". O caso trata de um imigrante nascido na Faixa e Gaza e que pediu asilo para o Reino Unido e obteve denegação ao seu direito. Desse julgamento, participaram os Lords Saville, Mance, Collins e Lady Hale. ${ }^{156}$

A terceira área mais tratada na Suprema Corte é a que analisa as relações empregatícias. O caso sob análise é o intitulado "Russell (Appellant) and others $v$ Transocean International Resources Limited and others (Respondents) (Scotland) \& Russell and others (Appellants) $v$ Transocean International Resources Limited and others Respondents) (Scotland)". O julgamento ocorreu no dia 7 de dezembro de 2011 e analisou a regulamentação do tempo de trabalho de 1998. Assim, analisa-se a regulamentação das horas de trabalho quando o trabalhador é marítimo, trabalhando em indústrias de gás e óleo. Esse caso ocorreu perante os Lords Hope, Brown, Mance, Kerr e Wilson. ${ }^{157}$

A quarta área de prevalência é a criminal. Com isso, analisou-se um julgamento ocorrido no dia 21 de março de 2012, intitulado "Flood (Respondent) v Times Newspapers Limited (Appellant)". Nesse caso, área do direito examinado foi difamação, haja vista tratar do caso de um sargento, integrante do Scotland Yard, que sofreu acusações de corrupção. O julgamento se deu perante os Lords Phillips, Brown, Mance, Clarke e Dyson. ${ }^{158}$

A quinta área de prevalência, e ultima estudada pela pesquisa, é a referente ao direito de família. O processo sorteado é intitulado "W (Children)". Ele traz o caso

\footnotetext{
${ }^{156}$ SUPREME COURT UK. MS (Palestinian Territories) (FC) (Appellant) v Secretary of State for the Home Department (Respondent). Disponivel em $<$ https://www.supremecourt.uk/decided-cases/docs/UKSC_2009_0122_Judgment.pdf $\geq$. Acesso em 28 de julho de 2017.

157 SUPREME COURT UK. Russell (Appellant) and others v Transocean International Resources Limited and others (Respondents) (Scotland) \& Russell and others (Appellants) v Transocean International Resources Limited and others Respondents) (Scotland). Disponivel em $<$ https://www.supremecourt.uk/cases/docs/uksc-2010-0231-judgment.pdf>. Acesso em 29 de julho de 2017.

158 SUPREME COURT UK. Flood (Respondent) v Times Newspapers Limited (Appellant).

Disponivel em

<https://www.supremecourt.uk/cases/docs/uksc-2010-0166-judgment.pdf>. Acesso em 30 de julho de 2017.
} 
de um pai que é acusado de abusar sexualmente a filha. Assim, analisa-se o direito de família, direito fundamental de uma criança viver em um lar seguro e sadio. $O$ julgamento ocorreu no dia 3 de março de 2010 e se deu pelos lords Walker, Brown, Mance, Ker e Lady Hale.

\subsection{Dos resultados referentes aos anos de 2010 a 2015 no Brasil}

Enquanto a Suprema Corte do Reino Unido teve 490 decisões nos anos de 2010 a 2015, o Supremo Tribunal Federal teve 623.531 decisões. Dentre essas decisões do STF, conseguimos destacar 64 casos notórios, que serão o objeto da análise da presente pesquisa. ${ }^{159}$

Diante desses casos notórios, conseguimos catalogar um total de 25 temas. Dentro desse tema, também foram destacados 5 prevalentes: Liberdade, Segurança Jurídica, Direitos Políticos, Acesso a Justiça e Devido Processo Legal.

Observou-se, dentro desses 5 destaques, os seguintes percentuais: 15,5\% dos casos notórios referem-se à Liberdade; $11,11 \%$ dos casos notórios referem-se à Segurança Jurídica; 7,8\% dos casos notórios referem-se a Direitos Politicos; $4,4 \%$ dos casos são referentes ao Acesso a Justiça e 4,4\% ao Devido Processo Legal. Essas áreas de prevalência somam $42,1 \%$ de todas as áreas tratadas nos casos notórios.

Vejamos:

159 SUPREME COURT UK. W (Children). DIsponivel em $<$ http://www.stf.jus.br/portal/cms/verTexto.asp?servico=estatistica\&pagina=decisoesinicio $>$. Acesso em 30 julho de 2017. 


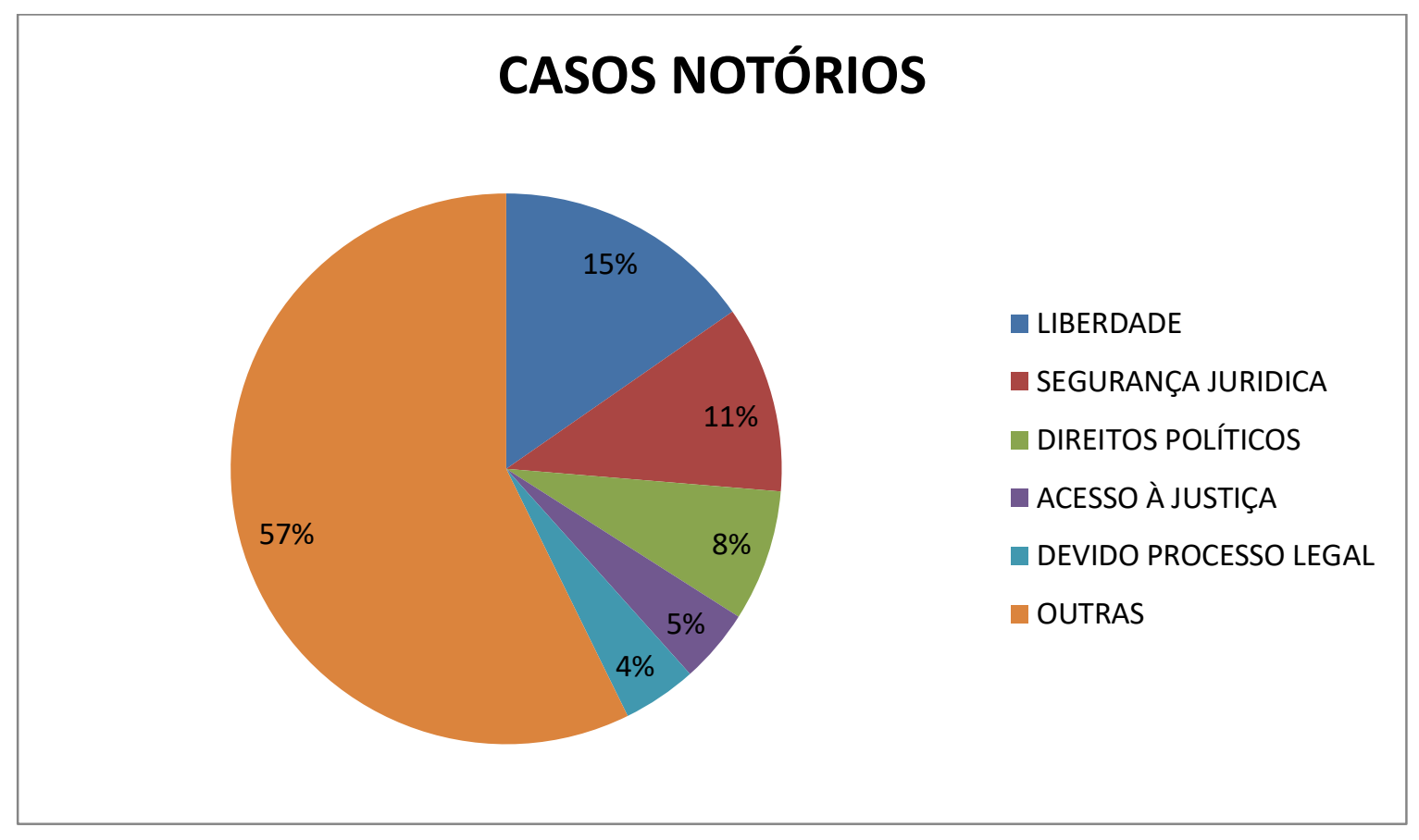

Da mesma forma em que foi feito no estudo da Inglaterra, foram escolhidos um caso referente a cada tema prevalente nos casos notórios de 2010 a 2015. Apenas a titulo de esclarecimento, o tema mais recorrente na Suprema Corte Inglesa são os Direitos Humanos, somando $11 \%$ de todas as decisões, enquanto, no Brasil, este tema soma 2,2\% das decisões de casos notórios .

O primeiro caso a ser analisado refere-se ao tema mais prevalente dentro dos casos notórios nesse lapso temporal, a liberdade. O julgamento foi o HC 104.339 e ocorreu no dia 10 de maio de 2012. Trata de paciente preso em flagrante e denunciado pela prática do delito descrito no art. 33, caput, c/c 40, III, ambos da Lei 11.343/2006. O relator foi o Ministro Gilmar Mendes. Formulado pedido de relaxamento da prisão em flagrante e/ou a concessão de liberdade provisória, este restou indeferido pelo Juízo da 22a Vara Criminal da Comarca de São Paulo (fl. 104). A defesa alega que a vedação legal, genérica e absoluta da liberdade provisória nos casos de tráfico choca-se com os princípios da excepcionalidade da prisão cautelar, do devido processo legal e da razoabilidade. ${ }^{160}$

O segundo tema sob análise trata do direito fundamental à segurança jurídica. O processo escolhido aleatoriamente para análise foi o RE 566621/RS,

\footnotetext{
160 SUPREMO TRIBUNAL FEDERAL. HC 104.339. Disponível em <http://redir.stf.jus.br/paginadorpub/paginador.jsp?docTP=TP\&doclD=3164259>. Acesso em 30 de julho de 2017.
} 
ocorrido no dia 4 de agosto de 2011, que trata da inovação interpretativa trazida pela LC 1818 de 2005 que reduziu o prazo de 10 anos contados do fato gerador para 5 anos do pagamento indevido. A ministra relatora foi a Ellen Gracie e o argumento da parte recorrente foi de que essa alteração atingia a segurança jurídica dos contribuintes. Contudo, o tribunal decidiu que essa alteração não passa de uma alteração interpretativa. ${ }^{161}$

O terceiro caso a ser analisado trata dos direitos políticos. Assim, o direito fundamental a tutela de direitos políticos representa $7,8 \%$ de todos os direitos fundamentais tutelados nos casos notórios. O caso é a ADI 1817, julgada no dia 28 de maio de 2014, cujo relator foi o ministro Dias Toffoli e cuida-se de ação direta de inconstitucionalidade, com pedido cautelar, proposta pelo então Partido Liberal (PL), extinto em 2006 com a criação do Partido da República (PR), com o objetivo de questionar a validade do art. 4 da Lei no 9.504/97 (Lei das Eleições), cujo teor determina que somente possa participar das eleições partido criado 1 ano antes do pleito. No fim, a ação foi julgada improcedente e reconhecida a constitucionalidade do artigo legal. ${ }^{162}$

O quarto caso sujeito a análise trata do direito fundamental ao acesso a justiça. O caso escolhido foi o Al 703269, da relatoria do Ministro Fux. Nesse processo, pleiteia-se pelo princípio da instrumentalidade do Direito Processual reclama a necessidade de interpretar os seus institutos sempre do modo mais favorável ao acesso à justiça (art. 5ํ, XXXV, CRFB) e à efetividade dos direitos materiais. No caso, as partes interpuseram embargos de declaração objetivando a reforma da decisão do relator com caráter infringente e pediam que fossem convertidos em agravo regimental (pelo principio da fungibilidade). No final, foram julgados procedes os embargos. ${ }^{163}$

O quinto caso a ser analisado trata do direito fundamental ao devido processo legal. Insta salientar que o percentual de casos notórios que trata desse assunto é o mesmo do que trata do direito fundamental ao acesso à justiça. Assim ambos tem o percentual de $4,4 \%$. O caso a ser analisado é o RE 279469 , da relatoria

\footnotetext{
${ }^{161}$ SUPREMO TRIBUNAL FEDERAL. RE 566621. Disponível em $<$ http://redir.stf.jus.br/paginadorpub/paginador.jsp?docTP=AC\&doclD=628479>. Acesso em 30 de julho de 2017.

162 SUPREMO TRIBUNAL FEDERAL. ADI 1817. Disponível em $<$ http://redir.stf.jus.br/paginadorpub/paginador.jsp?docTP=TP\&doclD=6422068>. Acesso em $31 \mathrm{de}$ julho de 2017.

163 SUPREMO TRIBUNAL FEDERAL. Al 703269. Disponível em $<$ http://redir.stf.jus.br/paginadorpub/paginador.jsp?docTP=TP\&doclD=8410473>. Acesso em 31 de julho de 2017.
} 
do Ministro Mauricio Correa, cujo julgamento se deu no dia 16 de março de 2011. A controvérsia gira em torno da extensão do afastamento previsto no inciso I do paragrafo 8 do artigo 14 da Constituição Federal - hipótese que se aplica aos militares com menos de 10 anos de tempo de serviço. O acesso a justiça é encontrado no caso pois este trata de afastamento militar e, a possibilidade de questionamento perante 0 Supremo Tribunal Federal demonstra a concretização desse acesso a justiça. 0 recurso foi provido pela maioria, contra o voto contrario do ministro relator. ${ }^{164}$

\section{CONCLUSÃO}

A utilização do método comparado em pesquisas no âmbito do direito constitucional produz consequências em diversos aspectos, sendo que os mais visíveis estão no plano da exegese das normas constitucionais de conteúdo semântico aberto e concretização indeterminada, o que facilmente pode ser exemplificada pelas normas constitucionais que declaram e/ou instituem direitos fundamentais.

O tema específico da comparação - sistemática de vinculação aos precedentes jusfundamentais nos ordenamentos brasileiro e inglês - é de ser destacado como de importância crucial para a sustentação do próprio modelo de Estado Constitucional Cooperativo. A investigação sobre o método comparativo e sua utilização na argumentação dos ministros do Supremo Tribunal Federal, especialmente quando estão a compor suas decisões constitucionais sobre direitos fundamentais, possibilitou concluir que nos últimos anos a Corte tem estado mais comprometida com o processo de referenciarão de precedentes estrangeiros.

No que tange ao precedente na Inglaterra, foi obtido contato com uma estudante de Direito do País, o que permitiu que se concluísse que não há uma matéria específica para o estudo do precedente no Reino Unido. Assim, este é estudado dentro de cada matéria e tema, mas isso não afasta sua importância dentro do sistema jurídico em questão.

O sistema do common law é baseado no sistema de precedente judicial. Cria-se a ideia de uma hierarquia, segundo a qual as decisões das Cortes Superiores obrigam às das Cortes Inferiores e à própria Corte prolatora da decisão A doutrina do

\footnotetext{
164 SUPREMO TRIBUNAL FEDERAL. RE 279469. Disponível em $<$ http://redir.stf.jus.br/paginadorpub/paginador.jsp?docTP=AC\&doclD=624269>. Acesso em 31 de julho de 2017.
} 
precedente faz com que os casos sejam decididos da mesma maneira quando os fatos materiais que cercam este são similares aos que ensejaram a primeira decisão.

Dos resultados obtidos nessa pesquisa, chegou-se às seguintes conclusões: a cada ano que passa, a Suprema Corte do Reino Unido tem tomado mais decisões, visto que a quantidade de decisões da Corte aumenta a cada ano. Contudo, ainda há uma diferença discrepante no que tange ao numero exato de decisões tomadas em cada uma das Cortes, visto que, enquanto na Suprema Corte houve 490 decisões entre os anos de 2010 a 2015, no STF tiveram 623.531 decisões! Assim, é nítido que no Brasil há uma maior facilidade no que tange à chegada de um caso à Corte Superior.

Em ambas as Cortes há um sitio eletrônico, no qual são divulgadas suas decisões e os jurisdicionados podem ter acesso ao inteiro teor de cada uma dessas. Contudo, ainda persistem diferenças entre os precedentes no common law inglês e no civil law brasileiro. O papel que os precedentes possuem no sistema do common law decorre da cultura jurídica que os países utilizadores desse sistema possui, trazendo a ideia de que o direito consiste naquilo que os antepassados decidiram e, consequentemente, desenvolveu em sua cultura jurídica. Já no civil law brasileiro não é assim. Inicialmente, tem-se que, antes do CPC de 2015, os casos que possuíam força vinculante com efeito erga omnes eram aqueles decorrentes de controle de constitucionalidade concentrado do STF, ação de declaração de constitucionalidade, inconstitucionalidade, arguição de preceito fundamental e nas súmulas vinculantes do STF. Após o CPC de 2015, aumentou-se o rol de decisões que passariam a ter efeitos vinculantes erga omnes, incluindo os casos de recursos especiais e extraordinários repetitivos, incidentes de resolução de demandas repetitivas e assunção de competência.

Portanto, ainda que o Novo Código de Processo Civil tenha aumentado a possibilidade de decisões vinculantes, a tendência de que houvesse um efeito vinculante já havia antes dele. Ou seja, ele é o resultado da alteração constante e gradativa sofrida pelo sistema jurídico brasileiro nos últimos anos, Mas isso não afasta a importância da lei dentro do ordenamento jurídico, visto que a importância material permanece ainda com o produzido a partir do legislativo.

Essas são diferenças marcantes entre o sistema jurídico inglês e o brasileiro: no inglês, tudo aquilo que chega à Corte Suprema adere uma força vinculante para o próprio Tribunal e para os Tribunais inferiores (ou seja, eficácia 
ergma omnes e ultra partes). No Brasil, há sempre uma força vinculante no sentido de que a decisão tomada pela Corte Superior vai vincular o tribunal inferior no sentido de alterar a decisão tomada anteriormente, mas não é sinônimo de que haverá eficácia erga omnes e ultra partes. Essa eficácia mais rígida da decisão, no sistema brasileiro, somente ocorrerá nesses casos determinados pela Constituição Federal e pelo Código de Processo Civil de 2015.

Todo esse fato justifica-se pelo resultado principal dessa pesquisa: a quantidade de decisões da Suprema Corte do Reino Unido é exorbitantemente inferior à quantidade de decisões do Supremo Tribunal Federal. Portanto, a própria sistemática de decisões de cada uma dessas Cortes justifica o fato de haver maior respeitabilidade das decisões de uma quando comparado com as da outra.

Portanto, a conclusão da presente pesquisa é a que os juristas brasileiros devem estudar a metodologia do precedente no sistema do common law de maneira demasiada, a fim de que este seja desenvolvido de maneira eficaz dentro do sistema jurídico nacional, uma vez que, se o acesso às Cortes Superiores continuar descomplicado da maneira que tem sido, o elevado número de decisões dessas Cortes impedirá que todas as suas decisões adquiram a eficácia erga omnes e ultra partes como possui um precedente no sistema do common law.

\section{REFERÊNCIAS}

ANDREASSA JUNIOR, Gilberto. Ativismo Judicial e Teoria dos Precedentes. Integração dos Poderes e Coerência nas Decisões do Judiciário, Curitiba: Juruá Editora, 2015.

OS "PRECEDENTES" NO SISTEMA JURÍDICO BRASILEIRO (STF E

STJ). Disponível em: < http://andreassaeandreassa.adv.br/wpcontent/uploads/2013/09/Os-precedentes-no-Brasil-STF-e-STJ.pdf> Acesso em: 08 dez. 2016.

BUENO, Cassio Scarpinella. Curso sistematizado de direito processual civil: Recursos. Processos e incidentes nos Tribunais. Sucedâneos recursais: técnicas de controle das decisões jurisdicionais. 2. ed. São Paulo: Saraiva, 2010. Vol. 5.

BRASIL. Constituição (1988). Constituição Federal da República Federativa do Brasil de 1988. Disponível em:

<http://www.planalto.gov.br/ccivil_03/Constituicao/Constituicao.htm>. Acesso em 13 de junho de 2017.

Lei 13.105 de 16 de março de 2015. Disponível em:

<http://www.planalto.gov.br/ccivil_03/_Ato2015-2018/2015/Lei/L13105.htm>. Acesso em 14 de junho de 2017. 
DIDIER JR., Fredie; OLIVEIRA, Rafael; BRAGA, Paula. Curso de direito processual civil. Salvador: Juspodivm, 2013.

DISTRITO FEDERAL. Tribunal de Justiça do Distrito Federal e Territórios. jurisprudência x precedente. Disponível em:

<http://www.tjdft.jus.br/institucional/imprensa/direito-facil/jurisprudencia-x-

precedente>. Acesso em 13 de junho de 2017.

DONIZETTI, Elpídio. A força dos Precedentes no Novo Código de Processo

Civil. Disponível em:

<file://C:/Users/batis/Desktop/MONO/A\%20forca\%20dos\%20precedentes\%20no\%2

Onovo\%20Codigo\%20de\%20Processo\%20Civil.pdf>.Acesso em 09 de junho de

2017.

DWORKIN, Ronald. 0 império do direito. 2. ed. $2^{a}$ tiragem. São Paulo: Martins Fontes, 2010.

HÄBERLE, Peter. El estado constitucional. Tradução de Hector Fix-Fierro. México: Universidad Nacional Autônoma de México, 2003.

KREBS, Hélio Ricardo Diniz. Sistemas de Precedentes e Direitos Fundamentais.

São Paulo: Editora Revista dos Tribunais LTDA, 2015.

LEAL, Diego de Lima. A doctrine of stare decisis a common law e os

precedentes judiciais. Disponível em:

$<$ https://diegoleal.jusbrasil.com.br/artigos/296841745/a-doctrine-of-stare-decisis-acommon-law-e-os-precedentes-judiciais $\geq$. Acesso em 07 de junho de 2017.

MARINONI, Luiz Guilherme. Julgamento nas Cortes Supremas: precedente e decisão do recurso diante do novo CPC. São Paulo: Editora Revista dos Tribunais LTDA, 2015. .

A Ética dos Precedentes, justificativa do novo CPC. São Paulo: Editora Revista dos Tribunais LTDA, 2014.

Aproximação crítica entre as jurisdições de civil law e de common law

e a necessidade de respeito aos precedentes no Brasil. Revista da Faculdade de Direito - UFPR, Curitiba: n.49, 2009.

O STJ enquanto corte de precedentes. Recompreensão do Sistema

Processual da Corte Suprema. São Paulo: Editora Revista dos Tribunais, 2013. Precedentes obrigatórios. 2. ed. São Paulo: Revista dos Tribunais, 2011.

MELLO, Patrícia Perrone Campos. O Supremo e os precedentes constitucionais: como fica a sua eficácia após o Novo Código de Processo Civil. Universitas JUS, v. 26, n. 2, 2015.

MITIDIERO, Daniel. Precedentes, da persuasão à vinculação. São Paulo: Editora Revista dos Tribunais LTDA, 2016.

RADBRUCH, Gustav. O Espírito do Direito Inglês e a Jurisprudência Anglo-

Americana. Rio de Janeiro: Editora Lumen Juris, 2010.

ROSSI, Júlio César. Precedente à Brasileira: A Jurisprudência Vinculante no

CPC e no Novo CPC. São Paulo: Editora Atlas, 2015.

SILVA, Christine Oliveira Peter da. Estado de Direitos Fundamentais. Disponível em <https://jus.com.br/artigos/42128/estado-de-direitos-fundamentais $\geq$. Acesso em 07 de julho de 2017.

SUPREME COURT UK. Decided Cases. Disponível em:

$<$ https://www.supremecourt.uk/decided-cases>. Acesso em 28 de julho de 2017.

Flood (Respondent) v Times Newspapers Limited (Appellant) Disponível em: <https://www.supremecourt.uk/cases/docs/uksc-2010-0166-judgment.pdf $\geq$. Acesso em 30 de julho de 2017. 
MS (Palestinian Territories) (FC) (Appellant) v Secretary of State for the Home Department (Respondent). Disponível em:

$<$ https://www.supremecourt.uk/decidedcases/docs/UKSC_2009_0122_Judgment.pdf $\geq$. Acesso em 28 de julho de 2017. . Russell (Appellant) and others $v$ Transocean International Resources Limited and others (Respondents) (Scotland) Russell and others (Appellants) $\mathbf{v}$ Transocean International Resources Limited and others (Respondents)

(Scotland). Disponível em: <https://www.supremecourt.uk/cases/docs/uksc-20100231-judgment.pdf $\geq$. Acesso em 29 de julho de 2017.

SUPREME COURT UK. Flood (Respondent) v Times Newspapers

Limited (Appellant). Disponível em:

<https://www.supremecourt.uk/cases/docs/uksc-2013-0243-judgment.pdf>. Acesso em 30 de julho de 2017.

SUPREMO TRIBUNAL FEDERAL. ADI 1.817 Disponível em

$<$ http://redir.stf.jus.br/paginadorpub/paginador.jsp?docTP=TP\&doclD=8410473>.

Acesso em 31 de julho de 2017.

. Estatísticas. Disponível em

$<$ http://www.stf.jus.br/portal/cms/verTexto.asp?servico=estatistica\&pagina=decisoesi nicio $\geq$. Acesso em 30 julho de 2017.

. HC 104.339. Disponível em

<http://redir.stf.jus.br/paginadorpub/paginador.jsp?docTP=TP\&doclD=3164259>.

Acesso em 30 de julho de 2017.

. HC 104.339. Disponível em

<http://redir.stf.jus.br/paginadorpub/paginador.jsp?docTP=TP\&doclD=6422068>. Acesso em 31 de julho de 2017.

. RE 279.469. Disponível em:

<http://redir.stf.jus.br/paginadorpub/paginador.jsp?docTP=AC\&doclD=624269 . Acesso em 31 de julho de 2017.

RE 566.621. Disponível em

$<$ http://redir.stf.jus.br/paginadorpub/paginador.jsp?docTP=AC\&doclD=628479>. Acesso em 30 de julho de 2017.

TEODORO, Rafael Theodor. A Teoria do stare decisis no controle de constitucionalidade brasileiro. Disponível em: <https://jus.com.br/artigos/25383/ateoria-do-stare-decisis-no-controle-de-constitucionalidade-brasileiro $\geq$. Acesso em 06/06/2017.

WIKIPEDIA. Antigo Regime. Disponível em

<https://pt.wikipedia.org/wiki/Antigo_Regime _. Acesso em 08 de junho de 2017. 